\title{
Klinik Araştırmalar: Türkiye'deki Güncel Mevzuatın Bir Özeti
}

\section{Clinical Trials: A Summary of the Current Regulations in Turkey}

\section{Yusuf ERGÜN}

${ }^{1}$ Prof. Dr. Kahramanmaraş Sütçü İmam Üniversitesi Tip Fakültesi Tıbbi Farmakoloji Anabilim Dalı, KAHRAMANMARAŞ

\section{Özet}

Klinik araştırmalarla ilgili ilk doküman 1993 yılında Sağlık Bakanlığı tarafından yayımlanan "İlaç Araştırmaları Hakkında Yönetmelik” olmuştur. Dünyadaki yeni gelişmelerle birlikte bu yönetmelik ihtiyaçları karşılayamaz hale geldiğinden günümüze kadar birçok yenileme gerekmiştir. Bugün yürürlükte olan son yönetmeliğe ek olarak birçok kanun, yönetmelik ve kılavuz da yayımlanmıştır. Bu derlemede klinik araştırmalar ile ilgili olan güncel mevzuat özetlenmiş ve günümüzde araştırmacıların dikkate alması gereken temel belgeler vurgulanmıştır.

Anahtar Kelimeler: Klinik araştırmalar; Mevzuat; Yönetmelik; Kılavuz

\section{Abstract}

First document regarding clinical trials was "By-law on Drug Investigations", which was published by Ministry of Health in 1993. Because the by-law had become insufficient to confront the needs occurred upon new developments in the world, several updates were required until today. In addition to the by-law being in force today, many statutes, by-laws and guidelines have been published as well. In the review, the current regulations concerning clinical trials have been summarized and essential regulations that should be considered by the investigators have been emphasized.

Key Words: Clinical trials; Regulation; By-law; Guideline

\section{GíRiş}

Yirminciyüzyılileivmekazananilaçaraştırmageliştirme faaliyetleri sırasında yürütülen temel araştırmalar, deney hayvanlarında yapılan klinik öncesi araştırmalar ve gönüllü insanlarda yürütülen klinik araştırmalar yeni bir ilacın ruhsatlandırılıp pazara sunulabilmesi için vazgeçilmez süreçlerdir. Klinik araştırmaların standartlarını belirlemek, gönüllülerin güvenliliğini sağlamak ve kamuoyunun bilimsel ve etik endişelerini gidermek için gelişmiş ülkelerde birçok düzenleyici doküman yazılmıştır. $\mathrm{Bu}$ gelişmelere paralel olarak Türkiye'de, biraz gecikmeli de olsa, konuyla ilgili çeşitli düzenlemeler yapılmıştır. Bu derlemede başta klinik araştırmalar ile ilgili yönetmelikler olmak üzere konuyla ilgili diğer kanunlar ve dokümanlar pragmatik bir bakış açısıyla özetlenmeye çalışılmıştır

\section{TARİHÇE}

Türkiye'de klinik araştırmalar ile alakalı olarak yürürlüğe giren ilk yönetmelik 29.01.1993 tarihinde 21480 sayılı resmi gazetede yayımlanan "İlaç Araștırmaları Hakkında Yönetmelik" olmuştur (1). İlk yönetmelikten çok sonra çıkarılan "Klinik Araştırmalar Hakkında Yönetmelik" 2008 yılında yayımlanmıştır (2). Sağlık Bakanlığının çok tartışma yaratan, içinde çok fazla yanlışlık ve eksiklik bulunan, bağımsız etik kurulları tam bağımlı hale

$\begin{array}{ll}\text { İletişim: } & \begin{array}{l}\text { Dr. Yusuf Ergün. KSÜ Tip Fakültesi Farmakoloji AD, } \\ \text { Kahramanmaraş }\end{array} \\ \text { DOI: } & \mathbf{1 0 . 1 7 5 1 7 / k s u t f d . 2 9 0 9 1 6}\end{array}$

getiren ve onun üyelerini bürokrata indirme hevesi olan bu yönetmelik 2009 y1lında Türk Tabipleri Birliği Merkez Konseyi Başkanlığı tarafindan T.C. Danıştay Onuncu Dairesine 2009/3991 esas nolu başvurusu ile mahkemelik olmuştur. Onuncu Dairede görüşülen dava sonucunda Bakanlığın, kanunda açık bir şekilde belirtilmese de, yönetmelik çıkarabileceği ifade edildikten sonra Y2'nin bazı kritik maddelerinin yürütmesi durdurulmuştur (3). Sonuç olarak mahkemenin bu kararı ile yönetmelik işlevsiz bir duruma gelmiş ve klinik araştırmalar bir süreliğine felç olmuştur. Bakanlık durumu toparlama adına 11.03.2010 tarihinde "Klinik Araştırmalar Hakkında Yönetmelikte Değişiklik Yapılmasına Dair Yönetmelik" adı altında yeni bir doküman yayımlamıştır (4). Onuncu Dairenin verdiği bu kısmi iptal kararına hem Bakanlık ve hem de Türk Tabipleri Birliği Merkez Konseyi Başkanlığı T.C. Danıştay İdari Dava Daireler Kurulu nezdinde itiraz etmiş̧ir. Danıştay İdari Dava Daireler Kurulu ise "kişinin vücut bütünlüğünün dokunulmazlığına müdahale, başka bir anlatımla bu hakkın sinırlandırılması ile ilgili olan" bu yönetmeliğin Anayasanın 13 ve 17'inci maddelerine göre yasa ile düzenlenmesi gerektiği ve dayanak kısmında belirtilen mevcut yasaların (181 ve 3359 sayılı kanunlar) Bakanlığa bu hakk1 vermediği kanaati ile yönetmeliğin tamamen iptaline karar vermiştir (5).

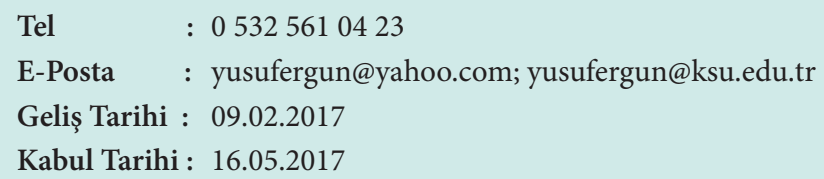




\section{Tablo 1}

\begin{tabular}{l|l}
\hline Y1l & Yönetmeliğin adı \\
\hline 1993 & İlaç Araştırmaları Hakkında Yönetmelik \\
\hline 2008 & Klinik Araştırmalar Hakkında Yönetmelik \\
\hline 2010 & Klinik Araştırmalar Hakkında Yönetmelikte Değişiklik Yapılmasına Dair Yönetmelik \\
\hline 2011 & Klinik Araştırmalar Hakkında Yönetmelik \\
\hline 2013 & Klinik Araştırmalar Hakkında Yönetmelik \\
\hline 2014 & Klinik Araştırmalar Hakkında Yönetmelikte Değişiklik Yapılmasına Dair Yönetmelik \\
\hline 2015 & İlaç ve Biyolojik Ürünlerin Klinik Araştırmaları Hakkında Yönetmelikte Değişiklik Yapılmasına Dair Yönetmelik \\
Güncel & İlaç ve Biyolojik Ürünlerin Klinik Araştırmaları Hakkında Yönetmelik \\
\hline
\end{tabular}

Bu mahkeme kararlarından sonra işaret edilen kanuni boşluğu doldurmak amacıyla sırasıyla iki düzenleme yapılmıştır: i) 3359 sayılı kanuna eklenen ek madde 10 (6), ii) Sağlık Bakanlığ ve Bağlı Kuruluşlarının Teşkilat ve Görevleri Hakkında Kanun Hükmünde Kararname (7). 3359 sayılı Sağlık Hizmetleri Temel Kanununa eklenen 10'uncu madde de temel alınarak 2011 yılında "Klinik Araştırmalar Hakkında Yönetmelik" adı altında 4'üncü yönetmelik çıkarılmıştır (8). Ardından Sağlık Bakanlığı 2 yıl sonra "Klinik Araştırmalar Hakkında Yönetmelik" adı altında yeni bir yönetmelik çıkarmıştır (9). Bakanlık bu yönetmelikte 2014 yılında bir revizyona gitmiş ve yönetmeliğin adını "İlaç ve Biyolojik Ürünlerin Klinik Araştırmaları Hakkında Yönetmelik" olarak değiştirmiştir (10). Son olarak yönetmelikte 2015 yılında kısa bir revizyon yapıldıktan sonra güncel hali ortaya çıkmıştır ( $\mathrm{Bu}$ makalede bundan sonra Yönetmelik olarak ifade edilecektir.) (11). 1993'ten günümüze kadar çıkarılan yönetmelikler ve yapılan revizyonlar Tablo 1'de özetlenmiştir.

\section{3. İlaç ve Biyolojik Ürünlerin Araştırmaları Hakkında Yönetmelik}

\subsection{Birinci Bölüm}

\subsubsection{Amaç}

Madde 1'de Yönetmeliğin amacı "taraf olunan uluslararası anlaşmalar ile Avrupa Birliği standartları ve iyi klinik uygulamaları (İKU) çerçevesinde, insanlar üzerinde bilimsel araştırma yapılması ve gönüllülerin haklarının korunmasına dair usûl ve esaslar ile Klinik Araştırmalar Danışma Kurulu ve etik kurulların teşkili, görevleri, çalışma usûl ve esaslarını düzenlemek" olarak tanımlanmıştır.

\subsubsection{Kapsam}

İkinci maddede biyoyararlanım ve biyoeşdeğerlik çalışmaları da dâhil olmak üzere ruhsat veya izin alınmış olsa dahi insanlar üzerinde yapılacak olan ilaç, tıbbi ve biyolojik ürünler ile bitkisel ürünlerin klinik araştırmalarının Yönetmelik kapsamında olduğu belirtilmiştir. Öte yandan retrospektif çalışmalar Yönetmeliğin kapsamı dişında tutulmuştur (Tablo II).

Kısaltmalar: TİTCK; Türkiye İlaç ve Tıbbi Cihaz Kurumu, KADB; Klinik Araştırmalar Dairesi Başkanlığı, TCOK; Tıbbi Cihaz Onaylanmış Kuruluş (Tıbbi cihaz yönetmelikleri (93/42/EEC, 98/79/EEC, 90/385/EEC) kapsamında uygunluk değerlendirme faaliyetinde bulunmak üzere Kurum tarafından ilgili mevzuatta belirlenen esaslar doğrultusunda görevlendirilen ve isimleri Avrupa Birliği Komisyonuna bildirilen Türkiye'de yerleşik uygunluk değerlendirme kuruluşudur.), SHGM; Sağlık Hizmetleri Genel Müdürlüğü

\subsubsection{Dayanak}

Mahkemenin 2010 yılında aldı ̆̆ yönetmelikle ilgili iptal kararından sonra çıkarılan Sağlık Hizmetleri Temel Kanunu'nun ek-10'uncu maddesi (6) ile Sağlı Bakanlığı ve Bağlı Kuruluşların Teşkilat ve Görevleri Hakkında Kanun Hükmünde Kararnamenin 27'inci ve 40'1nc1 maddeleri (7) dayanak olarak kullanılmıştır. Ayrıca Yönetmelik hazırlanırken Avrupa Birliği'nin ilaçlarla ilgili mevzuatının İKU hakkındaki 2001/20/EC (12) ve 2005/28/EC (13) sayılı direktifleri de dikkate alınmıştır.

Ek-10'uncu maddenin ilk paragrafina göre herhangi bir tedavi yöntemi veya araçlarının veyahut ruhsat veya izin alınmış olsa dahi ilaç ve terkipleri, geleneksel bitkisel tıbbi ürünler ile tıbbi cihazların bilimsel araştırma amaciyla insanlar üzerinde kullanılabilmesi için, Sağlık Bakanlığından izin alınması gerekmektedir (6). Burada dikkat edilmesi 
Klinik Araştırmalar Etik Kurulu

Ruhsat veya izin alınmış olsa dahi ilaç, tıbbi ve biyolojik ürünler ve bitkisel tıbbi ürünler ile yapılacak klinik araştırmalar (TITCK-KADB izni)

Genetik olarak modifiye edilmiş organizma taşıyan ürünler ile hücresel tedaviler veya gen tedavisi içeren ürünler kullanılarak yürütülecek araştırmalar

\section{İlaç dışı klinik araştırmalar}

Gözlemsel ilaç çalışmaları (Retrospektif çalışmalar hariç) (TITCK-KADB izni)

İlaçların Türkiye’de ruhsat aldığı endikasyonları, pozoloji ve uygulama şekillerinde, Sağlık Bakanlığının güncel tanı ve tedavi kılavuzlarına uygun olarak tedavisi devam eden hastalarda, spontan reçete edilen ilaca ait verilerin toplandığı epidemiyolojik çalışmalar

Tibbi cihaz klinik araştırmaları* (TİTCK-KADB+TCOK izni)

Bir veya daha fazla merkezde, tıbbi cihazın güvenlik, etkinlik veya performansını değerlendirmek için gönüllüler üzerinde yürütülen sistematik araştırma veya çalışmalar

\section{Gözlemsel tıbbi cihaz çalışmaları* (TİTCK-KADB+TCOK izni)}

Tıbbi Cihaz Yönetmeliklerine uygun olarak üzerine “CE” işareti iliştirilmiş cihaz veya cihazların, imalatçı tarafından belirtilen kullanım amaçları doğrultusunda spontan olarak kullanıldığı ve tıbbi cihaza ilişkin olarak klinik güvenlik veya performans verilerinin toplandığ çalışmalar

Biyoyararlanım ve Biyoeşdeğerlik Çalışmaları Etik Kurulu

Biyoyararlanım ve biyoeşdeğerlik çalışmaları (TİTCK-KADB izni)

Kozmetik Araştırmalar Etik Kurulü**

Kozmetik ürün/hammaddelerinin etkinlik veya güvenlilik çalışmaları (TİTCK izni)

Kozmetik ürün/hammaddelerinin klinik araştırmaları (TİTCK izni)

Yönetmeliğin kapsamı dışındaki araştırmalar

Retrospektif çalışmalar

Vücut dışında kullanılan (in vitro) tıbbi tanı cihazları ile yapılan performans değerlendirme çalışmaları ${ }^{*}$

* Tıbbi Cihaz Klinik Araştırmaları Yönetmeliğine göre dâhil edilen araştırmalar.

** Kozmetik Ürün veya Hammaddelerinin Etkinlik ve Güvenlilik Çalışmaları ile Klinik Araştırmaları Hakkında Yönetmeliğe göre dâhil edilen araştırmalar.

gereken nokta bakanlıktan izin alınmasını gerektiren koşulun bu ürünlerin ya da yöntemlerin "bilimsel araştırma amacıyla insan üzerinde kullanılması" durumudur. Çok büyük bir kısmı müdahaleli çalışma tasarımı şeklinde yürütülen klinik araştırmalarda gönüllü hastalara yapılan müdahale ya da işlem bilimsel araştırma amaciyla, örneğin yeni bir araştırma ilacının insanlar üzerinde kullanılması şeklinde, yapıldığından Sağlık Bakanlığından izin alınması kaçınılmazdır. Öte yandan "ilaçların Türkiye'de ruhsat aldığı endikasyonları, pozoloji ve uygulama şekillerinde, Bakanlığın güncel tanı ve tedavi kılavuzlarına uygun olarak tedavisi devam eden hastalarda, spontan reçete edilen ilaca ait verilerin toplandığı epidemiyolojik çalışmalar" şeklinde tanımlanan gözlemsel ilaç çalışmalarında hastalara ilaç uygulama işleminin bilimsel araştırma amacıyla olmadığı rutin tedavi hizmetleri çerçevesinde yapıldığı aşikârdır. Bu durumda bu tip çalışmalar için kanunen Sağlık Bakanlığından izin alınması gerekmese de uygulamada bunlar için de izin alınması talep edilmektedir. Bu çarpık durum ek-10'uncu maddede geçen "bilimsel araştırma amacıyla" ibaresi yerine "bilimsel araştırma veya gözlemsel ilaç/tıbbi cihaz çalışmaları kapsamında olduğu gibi rutin tanı ve tedavi amaciyla" ifadesi eklenerek düzeltilebilir. Ek-10'uncu maddenin devaminda a-f maddeleriyle vurgulanan şartlar Yönetmeliğin 5'inci maddesinde araştırmanın genel esasları başlı̆gı altında yerini bulmuştur. Ek-10 metninin devamında, bu araştırmaların üzerinde araştırma yapılacak kimselerin emniyetini sağlamaya ve araştırmanın sağlıklı bir şekilde yürütülebilmesine, takibine ve gereğinde acil müdahale yapılabilmesine elverişli ve araştırmanın vasfina uygun personel, teçhizat ve laboratuvar imkânlarına sahip olan şu yerlerde yapılabileceğine işaret edilmiştir: i) Üniversite sağlık uygulama ve araştırma merkezleri, ii) üniversitelere bağlı onaylanmış araştırma-geliştirme merkezleri, iii) Refik Saydam Hıfzıssıhha Merkezi ve iv) Sağlık Bakanlığ 1 eğitim ve araştırma hastaneleri. Buifadenin başlangıç kısmı yönetmeliğin 11'inci maddesinin ilk fikrasında da ifade edilmekle birlikte Gülhane Askeri 


\section{Tablo III. Yönetmeliğe göre klinik araştırma dönemleri.}

\section{Faz I veya I. Dönem}

Araştırma ürününün farmakokinetik özelliklerinin, toksisitesinin ve vücut fonksiyonlarına etkisinin tespit edilebilmesi için, araştırmanın niteliğine ve mahiyetine göre seçilmiş yeterli sayıda sağlıklı gönüllüye veya sağlıklı gönüllülerde çalışılmasına imkân olmayan durumlarda hasta gönüllülere uygulanmak suretiyle denendiği klinik araştırma dönemidir. Yeni geliştirilen bir araştırma ürününün, klinik öncesi farmakolojik, toksikolojik ve benzeri araştırmaları tam ve uygun deneysel yöntemler kullanılarak yapılmadan Faz I veya I. Dönem klinik araştırmalarına geçilemez.

\section{Faz II veya II. Dönem}

Araştırma ürününün terapötik doz sınırlarının, klinik etkililiğinin ve emniyetinin araştırılması amacıyla, araştırmanın niteliğine ve mahiyetine göre seçilmiş yeterli sayıda gönüllü hastaya uygulanmak suretiyle denendiği klinik araştırma dönemidir.

\section{Faz III veya III. Dönem}

Faz I ve Faz II dönemlerinden geçmiş araştırma ürünün, araştırmanın niteliğine ve mahiyetine göre seçilmiş, yeterli sayıda gönüllü hastaya uygulanarak, etkililiği, emniyeti, yeni bir endikasyon araştırması, farklı dozları, yeni veriliş yolları ve yöntemleri, yeni bir hasta popülasyonu ve yeni farmasötik şekiller yönünden denendiği klinik araştırma dönemidir.

\section{Faz IV veya IV. Dönem}

Türkiye'de ruhsat almış ürünlerin onaylanmış endikasyonları, pozoloji ve uygulama şekilleri, izinli ürünlerin ise önerilen kullanımlarına yönelik emniyetinin ve etkililiğinin daha fazla incelenmesi veya yerleşik diğer tedavi, ürün ve yöntemlerle karşılaştırılması için fazla sayıda gönüllü hasta üzerinde gerçekleştirilen klinik araştırma dönemidir.

T1p Akademisi ve askeri eğitim-araştırma hastaneleri de araştırma yapılabilecek yerlere dâhil edilmiştir. Ancak kanunda ismi geçen Refik Saydam Hifzıssıhha Merkezi ise Yönetmelikte yerini bulmamıştır. Yönetmelikler dayanak aldıkları kanunlara aykırı veya idarî sorumluluğunda olmak kaydıyla, belirtilen nitelikleri haiz diğer sağlik kurum ve kuruluşlarının da (özel hastaneler gibi) dâhil edilebileceği Yönetmelikte ifade edilmiştir. Ayrıca gözlemsel ilaç çalışması kapsamında veri toplama

\section{Tablo IV. Etik Kurulların yapısı.}

\section{Klinik Araștırmaları Etik Kurulu}

Tercihen iyi klinik uygulamaları kurallarına göre düzenlenmiş uluslararası klinik araştırmalara araştırmacı olarak katılmış olan ve tercihen farklı uzmanlık dallarından seçilmiş olan uzman hekimler

Farmakoloji alanında doktora yapmış veya bu alanda tıpta uzmanlık eğitimi almış kişi

Biyoistatistik alanında doktora yapmış bir kişi veya halk sağlı̆̆ı uzmanı ya da bu alanda doktora yapmış tıp doktoru

Biyomedikal alanında çalışan bir mühendis veya uzman; bulunmaması halinde, bir biyofizikçi veya fizyolog

Hukukçu

Sağlık meslek mensubu olmayan kişi

Varsa, tıp etiği veya deontoloji alanında doktora yapmış veya uzmanlığını almış kişi

\section{Biyoyararlanım-Biyoeșdeğerlik Araştırmaları Etik Kurulu}

Tercihen iyi klinik uygulamaları kurallarına göre düzenlenmiş uluslararası klinik araştırmalara araştırmacı olarak katılmıs olan uzman hekimler

Farmakoloji alanında doktora yapmış veya bu alanda tıpta uzmanlık eğitimi almış kişi

Biyoistatistik alanında doktora yapmış bir kişi veya halk sağlı̆̆ uzmanı ya da bu alanda doktora yapmış tıp doktoru

Tercihen biyofarmasötik, farmakokinetik veya farmasötik teknoloji alanında doktora yapmış eczacı

Farmasötik kimya veya analitik kimya alanında doktora yapmıș eczacı ya da bu alanlarda doktora yapmış kimyager ya da kimya mühendisi

Hukukçu

Sağlık meslek mensubu olmayan kişi

Varsa, tıp etiği veya deontoloji alanında doktora yapmış veya uzmanlığını almış kişi

yazılamayacağından bu merkezlerde de araştırma, hukuken, yapilabilir. Son olarak bu merkezler ve hastanelerde yapılan klinik araştırmalara, gereğinde bu merkezlerin ve hastanelerin koordinatörlüğünde işlemi sağlık kurumlarında/kuruluşlarında ve ayrıca gerekli izinlerin alınması koşuluyla saha taraması şeklinde doğrudan çalışmaya katılanlara ulaşılarak ya da ilgili veri tabanları yoluyla yapılabilir (14). Ek- 
Tablo V. Etik kurullardaki farmakolog üyenin niteliğinin yullara göre değişimi

\begin{tabular}{l|l}
\hline Yönetmelik & Farmakolog üye \\
\hline 1993 & 1 klinik farmakolog veya tıp doktoru farmakolog \\
\hline 2008 & Farmakoloji alanında doktora yapmış veya uzmanlığını almış, tercihen tıp doktoru, en az bir farmakolog \\
\hline 2011 & Farmakoloji alanında doktora yapmış veya uzmanlığını almış tıp doktoru veya eczacı \\
\hline 2013 & $\begin{array}{l}\text { Farmakoloji alanında doktora yapmış eczacı veya farmakoloji alanında doktora yapmış ya da uzmanlığını } \\
\text { almış tıp doktoru }\end{array}$ \\
\hline 2014 & Farmakoloji alanında doktora yapmış veya bu alanda tıpta uzmanlık eğitimi almıs kişi \\
\hline 2015 & Farmakoloji alanında doktora yapmış veya bu alanda tıpta uzmanlık eğitimi almış kişi \\
\hline
\end{tabular}

${ }^{\star}$ Klinik farmakolog tıp fakültesi mezunu olmak zorundadır.

10’uncu madde ile Sağlık Bakanlı̆̆ına etik kurullar ve Klinik Araştırmalar Danışma Kurulu teşkil etme hakkı verilmiştir. Ayrıca insanlar üzerinde bilimsel araştırma yapılmasına dair usul ve esaslar, Klinik Araştırmalar Danışma Kurulunun ve klinik araştırma alanlarına göre etik kurulların teşkili, görevleri, çalışma usul ve esaslarını detaylandırabilmek açısından Sağlık Bakanlığın yönetmelik çıkarma yetkisi de verilmiştir. Bu kanun maddesi sayesinde klinik araştırmalar kanuni bir zemine oturtulmuştur. 2011 yılında yayımlanan Sağlık Bakanlığı ve Bağlı Kuruluşların Teşkilat ve Görevleri Hakkında
Kanun Hükmünde Kararnamenin 27'inci maddesi uyarınca, Bakanlığın politika ve hedeflerine uygun olarak ilaçlar, ilaç üretiminde kullanılan etken ve yardimc maddeler, ulusal ve uluslararası kontrole tabi maddeler, tıbbî cihazlar, vücut dışı tıbbî tanı cihazları, geleneksel bitkisel tıbbî ürünler, kozmetik ürünler, homeopatik tıbbî ürünler ve özel amaçlı diyet gıdalar hakkında düzenleme yapmakla görevli Türkiye İlaç ve Tibbî Cihaz Kurumu (TITTCK) kurularak İlaç ve Eczacılık Genel Müdürlüğü (İEGM) yenilenmiş ve Yönetmelikte "kurum" başlığ 1 altındaki yerini almıştır (7). Burada bahsi

\section{Tablo VI. İlaç dışı klinik araştırmalar}

\section{Endüstriyel ileri tıbbi ürünlerle yapılan araştırmalar \\ Endüstriyel ileri tıbbi ürün: İnsan/hayvan doku ve hücrelerinden kaynaklanan, bir kaynaktan birden fazla insanın kullanımı için hazırlanan veya bir kişi için hazırlansa dahi içerisinde onaylanmamış endüstriyel ürün/gen tedavi ürünü içeren ileri tıbbi tedavi ürün}

\section{Endüstriyel olmayan ileri tıbbi ürünlerle yapılan araştırmalar}

Endüstriyel olmayan ileri tıbbi ürün: Bir hastanede ve uzman hekimin sorumluluğunda uygulanabilen, reçeteyle veya hastaya özel sipariş ile hazırlanan, üretiminde bu amaçla kullanım onayı olmayan endüstriyel bir bileşen bulunmayan, sadece o ülke içerisinde kullanılacak olan, özel kalite standartlarına göre hazırlanmış canlı hücresel ürünlerle, otolog dokular

\section{İleri tedavi edici tıbbi ürünlerle yapılan araştırmalar*}

İleri tedavi tıbbi ürün: Endüstriyel olarak üretilmiş veya endüstriyel işlemlere tabi gen tedavi tıbbi ürünleri, kök/somatik hücre tedavi ürünleri, doku mühendisliği ürünleri ve kombine ileri tedavi tıbbi ürünleri

\section{Tedavi amaçlı denemeler}

Bilinen tıbbi müdahale yöntemleri ile tedavisi mümkün olmayan hastalarda veya bu tedavi yöntemlerinin yüksek riskli olduğu durumlarda; bilimsel araştırma sonuçlarının henüz kesin bir nitelik taşımadığı durumlarda dahi hastalığın tedavisi konusunda elde edilmiş somut bazı faydalarından yola çıkılarak, hastanın veya yasal temsilcisinin rızası alınmak suretiyle, uzman hekim tarafindan, hastanede yapilan ve bilimsel kurallara uygun olan tedavi

\section{Kök hücre nakli araştırmaları** \\ Organ ve doku nakli araştırmaları ${ }^{\star *}$}

İlaç dışı standart tedavi uygulamaları

Etkililiği ve güvenliliği en az bir adet prospektif randomize kontrollü çalışmada gösterilmiş ve Science Citation Index veya Science Citation Index Expanded kapsamındaki bir dergide yayınlanmak suretiyle kabul edilmiş tedavi

\section{Geleneksel ve tamamlayıcı tıp uygulama yöntemleri ile yapılan araştırmalar*}

Akupunktur, apiterapi, fitoterapi, hipnoz, sülük uygulaması, homeopati, kayropraktik, kupa uygulaması, larva uygulaması, mezoterapi, proloterapi, osteopati, ozon uygulamasi, refleksoloji, müzikterapi

*Türkiye İlaç ve Tibbi Cihaz Kurumu iznine tabi; ${ }^{\star}$ Sağlık Hizmetleri Genel Müdürlüğü iznine tabi. 
Tablo VII. Yönetmelik kapsamında olmayan araştırma tipleri

Retrospektif araştırmalar
Kök hücre, kan, saç, tüy, tükürük, gaita, idrar, doku, radyolojik görüntü, biyokimya, mikrobiyoloji, patoloji materyalleri
üzerinde yapılacak araştırmalar
Vücut fizyolojisi ile ilgili araştırmalar
Hücre ve doku kültürü araştırmaları
Antropometrik ölçümlere dayalı yapılan araştırmalar
Anket ve benzeri bilgi toplama araçları ile yapıllan araştırmalar
Yaşam alışkanlıklarının değerlendirilmesi çalışmaları
İnsana doğrudan müdahale gerektirmeden yapılacak benzeri çalışmalar

geçen homeopatik tıbbî ürünler, özel amaçlı diyet gıdalar ve vücut dışı tıbbî tanı cihazları dışındaki tüm ürünlerle yapılan klinik araştırmalar klinik araştırmalar etik kurulunun incelemesi için Yönetmelik kapsamına alınmıştır (Bakınız Tablo II) (11). Ancak Yönetmelikte kapsam kısmında adı geçmeyen tıbbi cihaz klinik araştırmaları ile gözlemsel tıbbi cihaz çalışmaları "Tibbi Cihaz Klinik Araştırmaları Yönetmeliği” vasıtasıyla klinik araştırmalar etik kurulunun denetimi altına alınmıştır (Bakınız Tablo II) (15). Benzer olarak kozmetik ürün veya hammaddelerinin etkinlik veya güvenlilik çalışmaları ile kozmetik ürün veya hammaddelerinin klinik araştırmaları "Kozmetik Ürün veya Hammaddelerinin Etkinlik ve Güvenlilik Çalışmaları ile Klinik Araştırmaları Hakkında Yönetmelik" aracılığıyla Kozmetik Araştırmalar Etik Kurulu denetimine bırakılmıştır (Bakınız Tablo II) (16). Kurum, yani TíTCK, görev alanına giren ilaç, tıbbî cihaz ve yukarıda tanımlanan diğerürünlere ilişkin klinik araştırmalarla ilgili düzenlemeleri yapmak, izin vermek ve denetlemek ile görevli ve sorumlu olduğundan homeopatik tıbbî ürünler ve özel amaçlı diyet gıdalar ile yapılan çalışmaların da kurum iznine tabi olması ve Yönetmeliğin ona göre tazelenmesi gerekmektedir.

Ayrıca daha önceki yönetmeliklerde tanımlanan ancak bu Yönetmelikte bulunmayan bazı araştırma tipleri de mevcuttur ve bunlar şu şekilde sıralanabilir: i) İleri tedavi tıbbi ürünleri ile yapılacak klinik araştırmaları, ii) endüstriyel ileri tıbbi ürünlerle ve endüstriyel olmayan ileri tıbbi ürünlerle yapılacak araştırmalar, iii) kök hücre nakli araştırmaları, iv) organ ve doku nakli araştırmaları, v) (yeni) bir cerrahi metot araştırması, vi) cerrahi araştırmalar, vii) biyobenzer ürünler için kıyaslanabilirlik çalışmaları, viii) tedavi amaçlı denemeler, ix) ilaç dışı standart tedavi uygulamaları, x) insani amaçlı ilaca erken erişim program1. Ek-10'uncu maddeye göre herhangi bir tedavi yöntemi veya araçlarının bilimsel araştırma amaciyla insanlar üzerinde kullanılabilmesi için, Sağlık Bakanlığından izin alınması gerektiğinden, Yönetmelikte tanımlanmasa da, yukarıda sıralanan araştırma tiplerinden önemli bir kısmının etik kurul onayı ve Kurum izni gerektireceği yorumu yapılabilir.

Avrupa Birliğgi'nin ilaçlarla ilgili mevzuatının İKU hakkındaki 2001/20/EC say1l direktifine gelince, bu direktif insanlarda kullanılan tıbbi ürünlerle yapılan klinik araştırmaların yürütülmesinde kullanılan İKU açısından üye ülkelerin kanunlarının, düzenlemelerinin ve idari işlemlerinin birbirine yakınlaştırılması ile ilgilidir (12). Bu direktifin kapsam başlıklı birinci kısmında bahsi geçen tıbbi ürün (medicinal product) teriminin 65/65/EEC sayılı direktifte tanımlandığına işaret edilmiştir (17). Bu direktif incelendiğinde tıbbi ürünün iki şekilde tanımlandığı görülmektedir: i) İnsanlardaki veya hayvanlardaki hastalıkların önlenmesi veya tedavi edilmesi için sunulan herhangi bir madde veya maddeler kombinasyonu, ii) insanlara veya hayvanlara tıbbi bir tanı koymak veya insanların veya hayvanların fizyolojik bir fonksiyonu iyileştirmek, düzeltmek veya fizyolojik fonksiyonları modifiye etmek maksadıyla herhangi bir madde veya maddeler kombinasyonun verilmesi (17). Aynı direktifte madde (substance); insan (insan kanı, insankanürünleri), hayvan(mikroorganizmalar, tek parça/bütün hayvanlar, organ parçaları, hayvan sekresyonları, toksinler, ekstreler, kan ürünleri, vs.), bitkiler (mikroorganizmalar, bitkiler, bitki parçaları, bitki salgıları, ekstreler, vs.), kimyasallar (elementler, doğal olarak oluşan kimyasal maddeler ve kimyasal değişiklik ya da sentez suretiyle elde edilen kimyasal ürünler) şeklinde tanımlanmıştır (17). Aslında madde ile ilgili bu tanımlama "Beșeri Tıbbi Ürünlerin Ruhsatlandırma Yönetmeliği”nde de benzer şekilde ifadesini bulmuştur (18). Bu belgelerdeki tanımlamalara dayanarak Yönetmeliğin 
kapsamkısmındageçen ancaktanımlarkısmında tarifi verilmeyen tıbbi üründen ne anlaşılması gerektiği ortaya konabilir. 2001/20/EC say1l direktifte, ek olarak, müdahaleli olmayan (non-interventional) araştırmaların kapsam dışında olduğu ifade edilmiştir (12). Halbuki Yönetmelik retrospektif olanlar hariç gözlemsel, yani müdahaleli olmayan, çalışmaları da kapsamı içine almış bulunmaktadır. Bu kısımda, son olarak, biyoyararlanım ve biyoeşdeğerlik çalışmaları da dahil olmak üzere tüm klinik araştırmaların İKU (good clinical practice) prensiplerine göre yürütülmesinin şart olduğu vurgulanmıştır (12). bir uzmanlığa sahip bir kişi olması gerekmektedir (12). Ek olarak eğer klinik araştırma bir ekip olarak yürütülüyorsa araştırmacının ekip lideri olduğu ve sorumlu araştırmacı (principal investigator) olarak isimlendirilebileceği ifade edilmektedir (12). Açıkçası Avrupa Birliği'nde doktor olması gereken sorumlu araştırmacının uzmanlık veya doktora eğitimi almış olması gerekmezken ülkemizdeki uygulama ise bu yöndedir.

Her iki belgede de bulunan diğer tanımlar şunlardan ibarettir: Araştırma broşürü (investigator's brochure), araştırma protokolü (protocol), araştırma ürünü (investigational medicinal

\section{Tablo VIII. Kozmetik Klinik Araştırmalar Etik Kurullarının yapısı.}

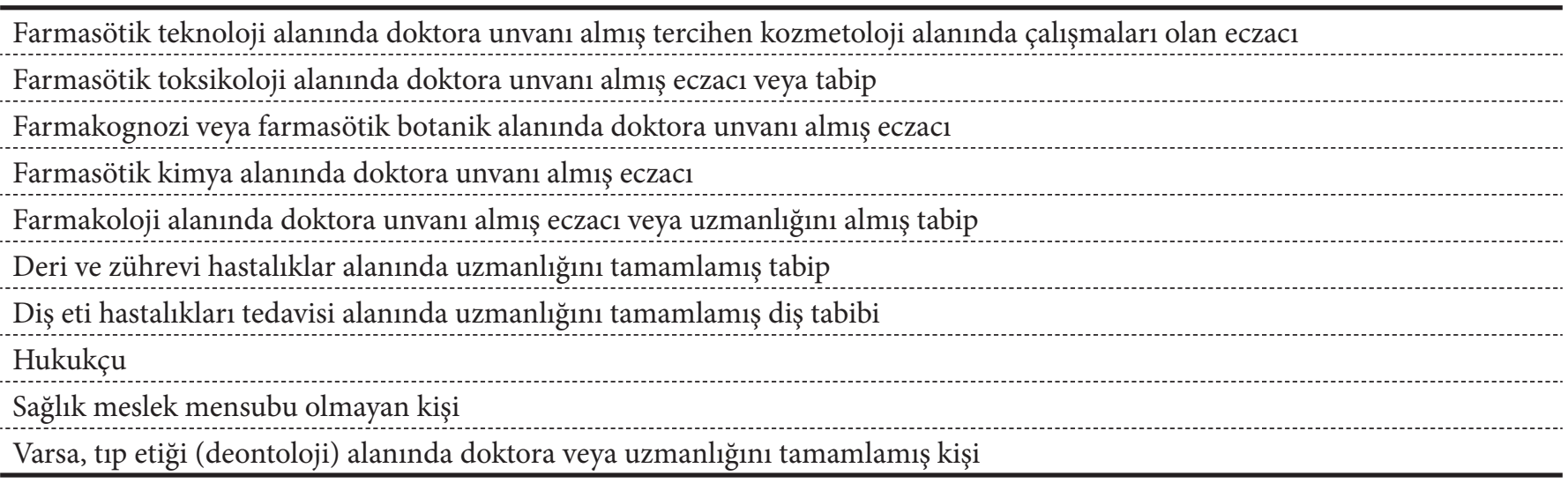

\subsubsection{Tanımlar}

Yönetmelikte madde 4'te geçen tanımlar büyük oranda 2001/20/EC sayılı direktiftekilerle paralellik göstermektedir. Nitekim advers olay (adverse event), advers reaksiyon (adverse reaction) ve ciddi advers olay veya reaksiyon (serious adverse event or reaction) her iki dokümanda da aynı şekilde tanımlanmıştır. Diğer taraftan Yönetmelikte beklenmeyen ciddi advers reaksiyon tanımı ile yetinilirken, direktifte daha kapsayıcı beklenmeyen advers reaksiyon (unexpected adverse reaction) tanımı kendine yer bulmuştur.

Yönetmelikte araştırmac1 (sorumlu araştırmacının gözetiminde klinik araştırmada yer alan kişi) ve sorumlu araştırmacı (araştırma konusu ile ilgili dalda uzmanlık veya doktora eğitimini tamamlamış olup, araştırmanın yürütülmesinden sorumlu olan hekim veya diş hekimi) ayrı ayrı tanımlanırken, direktifte sadece araştırmacı (investigator) başlığı altında bir tanımlama yapılmıştır. Bu tanımlamaya göre araştırmacının bir doktor ya da bilimsel geçmişi ve hastanın ihtiyaç duyduğu bakımı yapabilecek deneyime sahip olması nedeniyle üye ülkelerde araştırma için kabul gören product), bilgilendirilmiş gönüllü olur formu (informed consent), çok merkezli klinik araştırma (multi-center clinical trial), denetim (inspection), destekleyici (sponsor), etik kurul (ethics committee), gönüllü (subject), gözlemsel ilaç çalışması (noninterventional trial) ve klinik araştırma (clinical trial).

Yönetmelikte "klinik araştırmada test edilen veya referans olarak kullanılan aktif maddenin veya plasebonun farmasötik formu" olarak tarif edilen ve kapsam olarak temelde ilaçları hedefleyen araştırma ürünü direktifte biraz daha detaylandırılmış ve pazarlama izni almış fakat onaylanmış formundan farklı kullanılan ya da oluşturulan (formüle edilmiş veya paketlenmiş) ya da onaylanmamış bir endikasyonda kullanılan ya da onaylanmış formu hakkında daha fazla bilgi edinilmesi için kullanılan ürünler de bu tanıma dahil edilmiştir (12).

Direktifte bilgilendirilmiş rıza Yönetmeliğe kıyasla daha detaylı tarif edilmiş ve gönüllünün rıza vermeyeceği durumlarda kanuni temsilcisinden olur alınabileceği ve gönüllü okur-yazar değilse en az bir tanığın huzurunda sözel bilgilendirme yapılabileceği ifade edilmiştir (12).

Yönetmelikte etik kurul "gönüllülerin 
haklar1, güvenliği ve esenliğinin korunması amacıyla araştırma ile ilgili diğer konuların yanı sıra gönüllülerin bilgilendirilmesinde kullanılacak yöntem ve belgeler ile bu kişilerden alınacak olurlar hakkında bilimsel ve etik yönden görüş vermek üzere teşkil edilecek ve Kurumca onaylanacak bağımsız kurullar" şeklinde tanımlanmıştır. Direktifte ise bunlara ek olarak bağımsız olması gerektiği ifade edilen ve sağlık çalışanları ile tıp ile ilgisi olmayan üyelerden oluşması gereken bu kurulların araştırmacıların uygunluğunu da sorgulayacağ ve gönüllünün güvenliği açısından kamuoyunun endişelerini gidereceği de ifade edilmiştir (12).

Yönetmelikte "ilaçların Türkiye'de ruhsat aldığı endikasyonları, pozoloji ve uygulama şekillerinde, Bakanlığın güncel tanı ve tedavi kılavuzlarına uygun olarak tedavisi devam eden hastalarda, spontan reçete edilen ilaca ait verilerin toplandığı epidemiyolojik çalışmalar" şeklinde tanımlanan gözlemsel ilaç çalışması ile ilgili bazı hususlara direktifte açılamalar getirilmiştir. Nitekim bu tip çalışmalarda hastanın belirli bir tedavi stratejisine dahil edilmesi işleminin bir klinik araştırma protokolüne göre yapılmadığı fakat hastanın bu işleme rutin tedavi koşullarında maruz kaldığı ve ilacın hastaya verilmesinin hastanın klinik araştırmaya dahil edilmesi sürecinden açıkça ayrı olduğu belirtilmiştir (12).

Klinik araştırma direktife paralel olarak Yönetmelikte şu şekilde tanımlanmıştır: "Bir veya birden fazla araştırma ürününün klinik, farmakolojik veya diğer farmakodinamik etkilerini ortaya çıkarmak ya da doğrulamak; advers olay veya reaksiyonlarını tanımlamak; emilim, dağılım, metabolizma ve atılımını tespit etmek; güvenliliğini ve etkililiğini araştırmak amacıyla insanlar üzerinde yürütülen çalışmalar”. Hem Yönetmelikte hem de direktifte ana odağın, araştırma ürünü tanımı da dikkate alındığında, ilaç olduğu aşikardır. Halbuki, uygulamada tıbbi cihaz gibi ilaç dışında birçok farklı ürünün de araştırma ürünü olarak kabul edildiği ve bunlarla yapılan çalışmaların da klinik araştırma kapsamına alındığı bilinmektedir (Bakınız Tablo II).

Direktifin tanımlar kısmında bulunmayan fakat Yönetmelikte yer alan belli başlı terimler şöyle sıralanabilir: Bağıl biyoyararlanım, Bakanlık (Sağlık Bakanlığı), biyoeşdeğerlik, biyoyararlanım, ilaç veya beşeri tıbbi ürün, iyi klinik uygulamaları, kısıtlı, Klinik Araştırmalar Danışma Kurulu, Kurum (Türkiye İlaç ve Tıbbi Cihaz Kurumu), mutlak biyoyararlanım, sözleşmeli araştırma kuruluşu (contract research organization), idarî sorumlu, kanunî temsilci ve koordinatör. Türk Medeni Kanunun "Vesayeti Gerektiren Hâller" başlı̆̆ altında düzenlenen 405-408 maddelerine göre tanımlanan kısıtlılık halleri şunlardır: i) Akıl hastalığ veya akıl zayıflığ (Madde 405: Akıl hastalığı veya akıl zayıflığ 1 sebebiyle işlerini göremeyen veya korunması ve bakımı için kendisine sürekli yardım gereken ya da başkalarının güvenliğini tehlikeye sokan her ergin kisitlanır.), ii) Savurganlık, alkol veya uyuşturucu madde bağımlılı̆̆ 1 , kötü yaşama tarzı, kötü yönetim (Madde 406: Savurganlığı, alkol veya uyuşturucu madde bağımlılığı, kötü yaşama tarzı veya malvarlı̆̆ını kötü yönetmesi sebebiyle kendisini veya ailesini darlık veya yoksulluğa düşürme tehlikesine yol açan ve bu yüzden devamlı korunmaya ve bakıma muhtaç olan ya da başkalarının güvenliğini tehdit eden her ergin kısıtlanır.), iii) Özgürlüğü bağlayıcı ceza (Madde 407: Bir yıl veya daha uzun süreli özgürlüğü bağlayıcı bir cezaya mahkûm olan her ergin kısitlanır.), iv) İstek üzerine (Madde 408: Yaşlılığı, sakatlığ 1 , deneyimsizliği veya ağır hastalığı sebebiyle işlerini gerektiği gibi yönetemediğini ispat eden her ergin kısıtlanmasını isteyebilir.) (19).

\section{2. İkinci Bölüm}

\subsubsection{Araştırmanın genel esaslart}

Madde 5'te gönüllüler üzerinde araştırma yapılabilmesi için gerekli hususlar sıralanmıştır. Öncelikle araştırmanın, insan dışı deney ortamında veya yeterli sayıda deney hayvanı üzerinde yapılmış olması ve insan diş1 deney ortamında veya hayvanlar üzerinde yapılan deneyler sonucunda ulaşılan bilimsel verilerin, varılmak istenen hedefe ulaşmak açısından bunların insan üzerinde de yapılmasını zorunlu kılması gerekmektedir. Araştırmadan beklenen bilimsel faydalar ve kamu menfaati, araștırmaya iştirak edecek gönüllü sağlığından veya sağlı̆̆ 1 bakımından ortaya çıkabilecek muhtemel risklerden ve diğer kişilik haklarından daha üstün tutulamayacağ 1 gibi araştırmayla varılmak istenen amacın, bunun kişiye yüklediği külfete ve kişinin sağlığ 1 üzerindeki tehlikeye göre daha ağır basması gerekir. Ayrıca araştırmanın insan sağlığı üzerinde öngörülebilir zararlı ve kalıcı bir etki bırakmaması şarttır. Elde edilecek faydaların araştırmadan doğması muhtemel risklerden daha fazla olduğuna etik kurulca kanaat getirilmesi hâlinde etik kurulun onayı ve Kurum izni alındiktan sonra araştırma başlatılabilir. 2001/20/EC sayıl direktifte bunlara benzer ifadeler bulunmakta ve orada etik kurul ile 
birlikte adi geçen yetkili otorite (competent authority) Yönetmelikteki TíTCK'e karşılık gelmektedir (12). Yönetmeliğin 5'inci maddesinde, spesifik olarak, gönüllüye ait germ hücrelerinin genetik yapısını bozmaya yönelik hiçbir araştırma yapılamayacağ vurgulanmıştır.

Araştırmaya iştirak etmek üzere gönüllü olmak isteyen kişi veya kanunî temsilcisi, araştırmaya başlanılmadan önce; araştırmanın amac1, metodolojisi, beklenen yararları, öngörülebilir riskleri, zorlukları, kişinin sağlığı ve şahsi özellikleri bakımından uygun olmayan yönleri ve araştırmanın yapılacağı, devam ettirileceği şartlar hakkında ve araştırmadan istediği anda çekilme hakkına sahip olduğu hususunda yeterince ve anlayabileceği şekilde araştırma konusuna hâkimiyeti olan araştırma ekibinden bir sorumlu araştırmacı veya hekim ya da diş hekimi olan bir araştırmacı tarafından bilgilendirilir. Diğer taraftan 2001/20/EC say1l direktifte bu bilgilendirmeyi araştırmacı (Yönetmelikteki sorumlu araştırmacıya tekabül etmektedir.) veya araştırma ekibinde bir kişi yapmakta olup Yönetmelikteki gibi hekim ya da diş hekimi olma şartı yoktur (12). Aslında Yönetmelikteki bu düzenleme araştırmacı tanımıyla da çelişen bir durumdur (Tanımlar kısmında bakınız). Gönüllünün tamamen serbest iradesi ile araştırmaya dâhil edileceğine dair herhangi bir menfaat teminine bağlı bulunmayan rızası alınır ve bu durum Bilgilendirilmiş Gönüllü Olur Formu ile belgelenir. Ayrıca gönüllü, gerekçeli veya gerekçesiz olarak, kendi rızasıyla, istediği zaman araştırmadan ayrilabilir ve bundan dolayı sonraki tıbbi takibi ve tedavisi sırasında mevcut haklarından herhangi bir kayba uğratılamaz. Önemli diğer bir nokta, gönüllülerin klinik araştırmadan doğabilecek zararlara karşı güvence altına alınması amacıyla faz IV klinik araştırmaları ve gözlemsel ilaç çalışmaları dışındaki klinik araştırmalara katılacak gönüllüler için sigorta yaptırılmasının zorunlu olmasıdır. Bununla ilintili olarak, sigorta teminatı dışında gönüllülere herhangi bir ikna edici teşvikte veya malî teklifte bulunulamaması da dikkate değer bir husustur. Ancak gönüllülerin araştırmaya iştiraki ile ortaya çıkacak masraflar ile sağlıklı gönüllülerin çalışma günü kaybından doğan gelir azalması araştırma bütçesinde belirtilir ve bu bütçeden karşılanır.

\subsection{2. Çocukların araştırmaya iştirak etmeleri}

Yönetmelikte çocuklar, gebeler, lohusalar ve emziren kadınlar, kısıtlılar ve yoğun bakımdaki ve bilinci kapalı kişiler için ayrı başlıklar açılmışken 2001/20/EC sayılı direktifte gayri reşit olanlar (minors) ve ehliyeti olmayan erişkinler (incapacitated adults) olmak üzere iki başl1k açılmıştır (12). Direktifteki gayri reşit olanlarla kast edilen çocuklardır ve Yönetmelikte madde 6'da direktifle paralel düzenlemeler yapılmıştır. Direktifte bahsi geçen yazılı olur veremeyen ehliyeti olmayan erişkinlere demanslı hastalar ve psikiyatrik hastalar vb. örnek olarak gösterilmiş olup bunun Yönetmelikteki karşılığı kısıtlılar ve yoğun bakımdaki ve bilinci kapalı kişilerdir.

Madde 6'nın 1'inci fikrasında; araştırma konusunun doğrudan çocukları ilgilendirdiği veya sadece çocuklarda incelenebilir klinik bir durum olduğu ya da yetişkin kişiler üzerinde yapılmış araştırmalar sonucu elde edilmiş verilerin çocuklarda da geçerliliğinin kanıtlanmasının zorunlu olduğu durumlarda araştırma yapılmasına izin verilebileceği ifade edilmiştir. Çocuk rızasını açıklama yetisine sahip ise kendi rızasının yanı sıra ana ve babasının veya vesayet altında ise vasisinin yazılı olarak oluru alınması gerekmektedir. Ek olarak çocuk kendisine verilen bilgi hakkında değerlendirme yapabilecek ve bu konuda bir kanaate varabilecek kapasitede ise, araştırma ile ilgili gerekli tüm bilgiler çocuğa uygun bir şekilde anlatılır. Etik kurul, araştırmayla ilgili klinik, etik, psikolojik ve sosyal problemler konusunda çocuk sağlığı ve hastalıkları uzmanı bir hekim tarafindan bilgilendirilir ve protokol bu yönde değerlendirilir. Çocuklarda yapılacak her türlü klinik araştırmada çocuk sağlığı ve hastalıkları uzmanı bir hekimin araştırmanın çocuklar üzerinde yapılması hususunda müspet görüşü olmadan etik kurul bu araştırmaya onay veremez. Bu son hüküm 2001/20/ EC sayılı direktifte bulunmamaktadır (12). Bu çalışmalar için gerekli görülmesi halinde araştırma konusu ile ilgili bilim dalından doktora veya uzmanlığını almış hekim ya da diş hekiminin görüşü alınır ve araştırmaya izin verilip verilemeyeceği bu görüş sonucunda değerlendirilir.

\subsubsection{Gebeler, lohusalar ve emziren kadınların araştırmaya iştirak etmeleri}

Araştırma konusunun doğrudan gebe, lohusa veya emziren kadınları ilgilendirmesi ya da sadece gebe, lohusa veya emziren kadınlarda incelenebilir klinik bir durum olması hâlinde araştırma yapılmasına izin verilebilir. Ayrıca araştırma gönüllü ile fetüs veya bebek sağlığı açısından öngörülebilir bir risk taşımıyor ve araştırmanın gönüllülere doğrudan bir fayda sağlayacağ1 hususunda genel 
Tablo IX. Klinik Araştırmalar ile ilgili kılavuzlar.

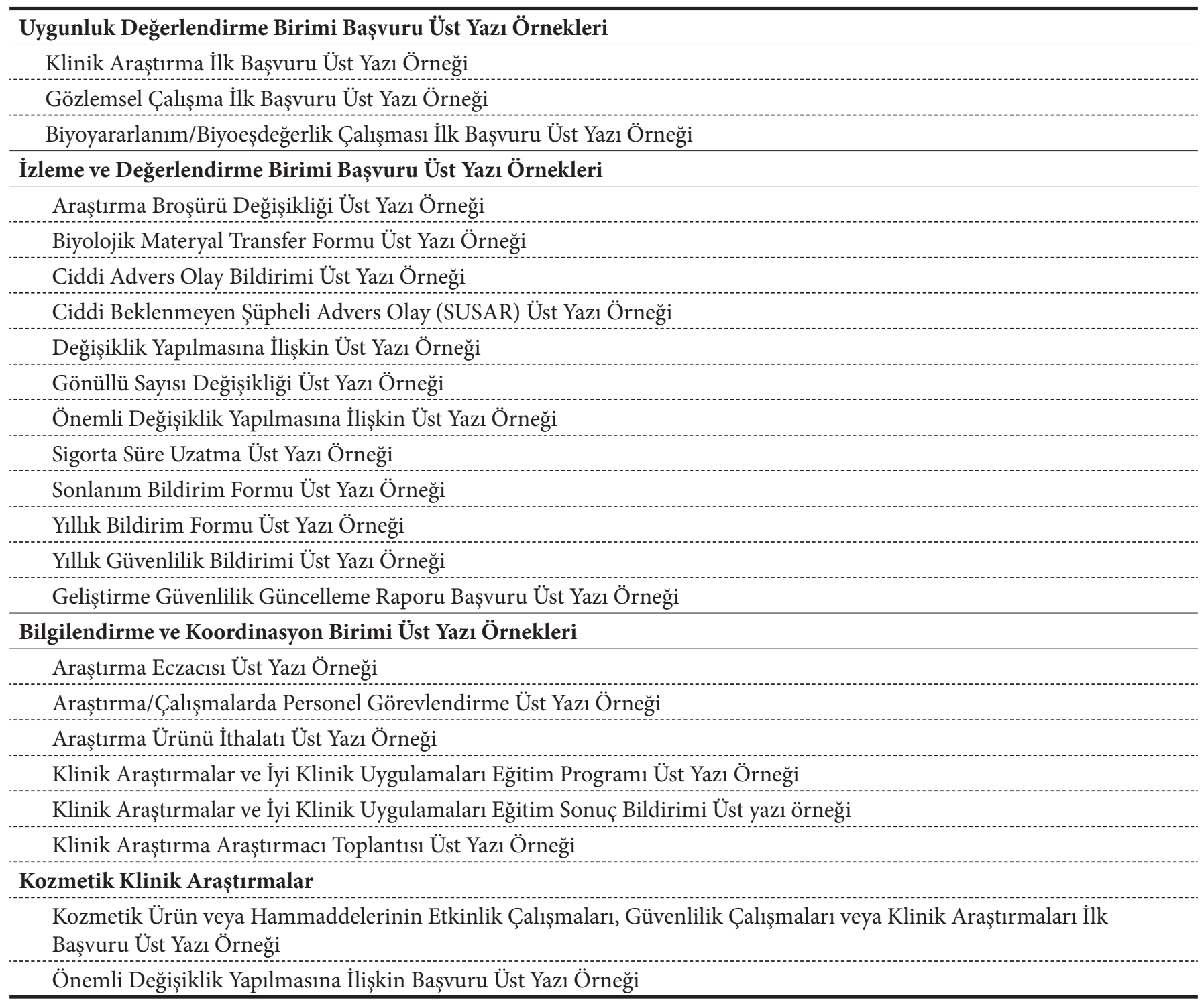

tıbbi bir kanaat bulunuyor olması gerekir. Etik kurul, özellikle fetüs veya bebek sağlığı yönünden, araştırmayla ilgili klinik, etik, psikolojik ve sosyal problemler konusunda, araştırma konusu ile ilgili alanda uzmanlığını almış bir hekim tarafından bilgilendirilir ve protokol bu yönde değerlendirilir.

\subsubsection{Kisıtlıların araştırmaya iştirak etmeleri}

Her ne kadar 2001/20/EC sayılı direktifteki ehliyeti olmayan erişkinler ile tam örtüşmese de madde 8'de araştırma konusunun doğrudan kısıtlılık hâlleri kapsamındaki kişileri ilgilendiren ya da sadece kisitlilarda incelenebilir bir durum olması hâlinde veya kısıtlının hastalığıyla ilgili mevcut tedavi seçeneklerinin tamamen tüketildiği durumlarda, araştırma kısıtlı sağlığı açısından öngörülebilir bir risk taşımıyor ve araştırmanın kısıtlılık hâlleri kapsamındaki kişilere doğrudan bir fayda sağlayacağı hususunda genel tıbbi bir kanaat bulunuyorsa araştırma yapılmasına izin verilebileceği, hükme bağlanmıştır. Rızasını açıklayabilecek yetiye sahip ise kısıtlının rızası ile birlikte vasisinin yazılı olurları alınır. Kısıtlı, kendisine verilen bilgi hakkında değerlendirme yaparak bu konuda kanaate varabilme kapasitesine sahip ise, araştırmaya iştirak etmeyi reddetmesi veya araștırmanın herhangi bir safhasında araştırmadan çekilmek istemesi durumlarında araştırmadan derhal çıkarılır. Etik kurul, araştırmayla ilgili klinik, etik, psikolojik ve sosyal problemler konusunda, araştırma konusu ile ilgili alanda uzmanlığını almış bir hekim ile psikiyatri uzmanı bir hekim tarafından bilgilendirilir ve protokol bu yönde değerlendirilir. $\mathrm{Bu}$ son durumda bahsi geçen psikiyatri uzmanı vurgusu 2001/20/EC say1lı direktifte bulunmamakta olup sadece ilgili hastalıkla ilgili uzmandan görüş alınmaktadır (12).

\subsubsection{Yoğun bakımdaki ve bilinci kapalı kişilerin araştırmaya iştirak etmeleri}


Tablo X. Klinik Araştırmalar ile ilgili üst yazı örnekleri.

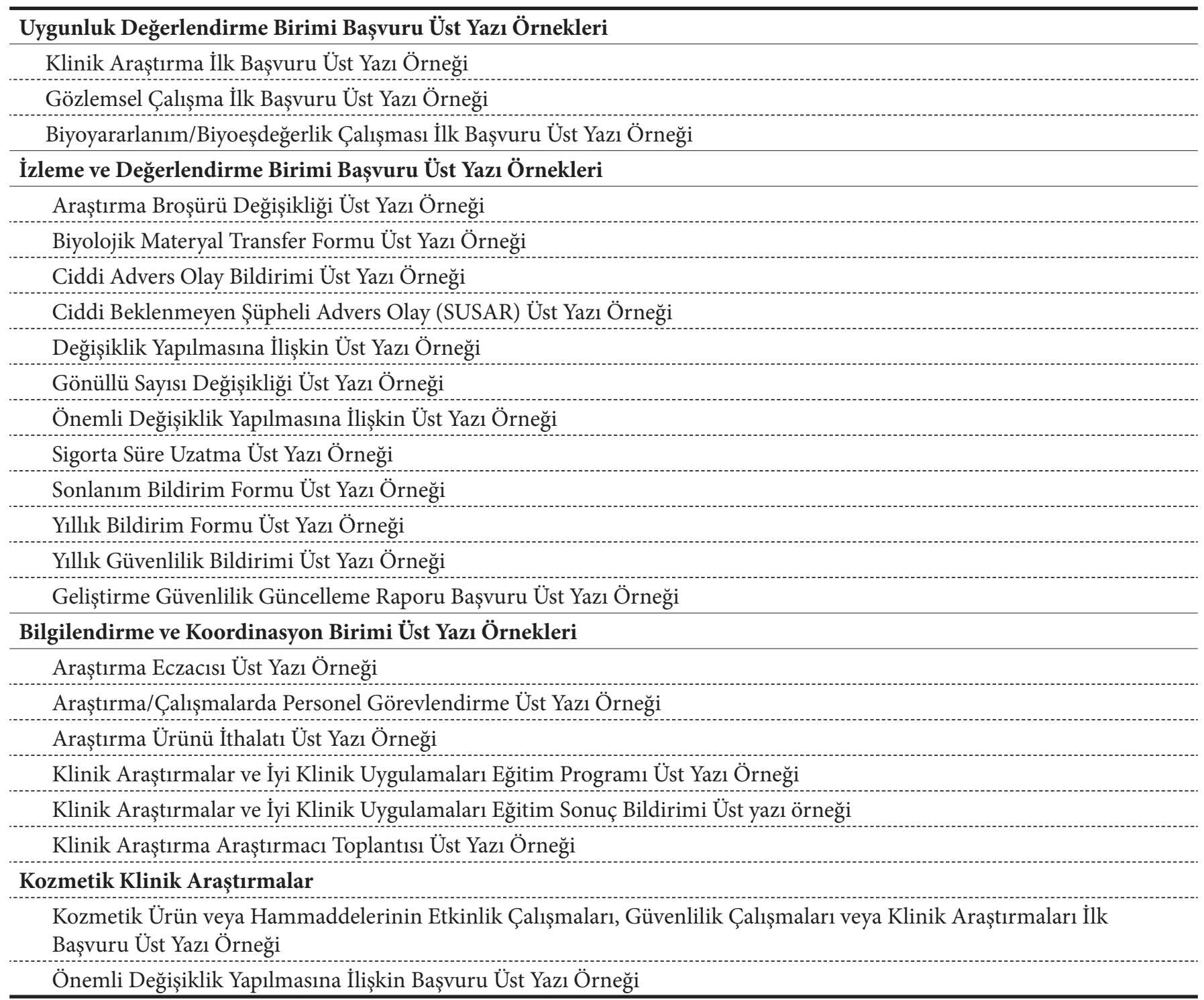

2001/20/EC sayılı direktifteki ehliyeti olmayan erişkinler anlayışıyla paralellik gösteren bu grup için araştırmalar madde 9'da düzenlenmiştir. Araştırma konusunun doğrudan yoğun bakımdaki ve bilinci kapalı kişileri ilgilendiren ya da sadece yoğun bakımdaki ve bilinci kapalı kişilerde incelenebilir bir durum olması hâlinde veya yoğun bakımdaki ve bilinci kapalı kişilerin hastalığıyla ilgili mevcut tedavi seçeneklerinin tamamen tüketildiğ durumlarda, araştırma yoğun bakımdaki ve bilinci kapalı kişilerin sağlığı açısından öngörülebilir bir risk taşımıyor ve araştırmanın yoğun bakımdaki ve bilinci kapalı kişilere doğrudan bir fayda sağlayacağ 1 hususunda genel tıbbi bir kanaat bulunuyorsa araştırma yapılmasına izin verilebilir. Yoğun bakımdaki ve bilinci kapalı kişilerin varsa kanunî temsilcileri yoksa yakınları bilgilendirilir ve yazılı olurları alınır. Yoğun bakımdaki ve bilinci kapalı kişiler, kendisine verilen bilgi hakkında değerlendirme yaparak bu konuda kanaate varabilme kapasitesine sahip hale gelirlerse, araştırmaya iştirak etmeyi reddetmeleri veya araştırmanın herhangi bir safhasında araştırmadan çekilmek istemeleri durumlarında araştırmadan derhal çıkarılırlar. Etik kurul, araştırmayla ilgili klinik, etik, psikolojik ve sosyal problemler konusunda, araştırma konusu ile ilgili alanda uzmanlığını almış bir hekim tarafından bilgilendirilir ve protokol bu yönde değerlendirilir. Yoğun bakımdaki ve bilinci kapalı kişilerin kanunî temsilcilerine ya da yakınlarına ulaşılamaması ve yazılı olurlarının alınamaması durumlarında, sorumlu araştırmaci veya hekim olan bir araştırmacının sorumluluğunda, yoğun bakımdaki ve bilinci kapalı kişiler araştırmaya şu şartlarda dâhil edilebilir: i) Önerilen araştırma protokolü veya diğer belgelerin, söz konusu araştırmadaki etik hususları yeterince karşılayıp karşılamadıklarını etik kurulun önceden değerlendirmiş olmas1, ii) kardiyak arrest, kafa travması, santral sinir sistemi enfeksiyonları, beyin içi kanamaları gibi ani gelişip hekimin 
hemen müdahale etmesi gereken ve mevcut tedavi seçeneklerinin tamamen tüketildiği durumlarda, yoğun bakımdaki ve bilinci kapalı kişilere araştırmanın doğrudan bir fayda sağlayacağına yönelik genel tıbbi bir kanaatin bulunması.

\section{3. Üçüncü Bölüm}

\subsubsection{Klinik araştırma dönemleri}

Yönetmeliğin 10'uncu maddesinde klinik araştırma dönemleri tanımlanmıştır (Tablo III).

\subsubsection{Klinik araştırma yapılacak yerler, standartları ve izin başvurusu}

On birinci maddenin ilk fikrası yukarıda Sağlık Hizmetleri Temel Kanunu'nun ek-10'uncu maddesi çerçevesinde tartışılmıştır. Buna ek olarak 2'inci fikrada faz I klinik araştırmaları ve biyoyararlanımbiyoeşdeğerlik çalışmalarının TITCK' in onayladığı, acil müdahale yapılabilmesine elverişli imkânlara ve her biri için ayrı belirlenmiş standartlara sahip, Bakanlık veya üniversitelere bağlı olan sağlık kurum ve kuruluşlar ile araştırma-geliştirme merkezlerinde yapılabileceği ifade edilmiştir.

\subsubsection{Araştırma başvurusu ve izni}

Madde 12'ye göre klinik araştırmalara izin almak için etik kurul ile Kuruma eş zamanlı başvuru yapılabilir. $\mathrm{Bu}$ yaklaşım sakıncalı bir durum olup iki başlılığa neden olabilir. Klinik araştırma yapılabilmesi için sırasıyla etik kuruldan onay ve Kurumdan izin alınması gerekmekte olup ardışık bu iki olay birbirini tamamlar niteliktedir (2001/20/ EC sayılı direktifte de bu durum benzer bir şekilde düzenlenerek klinik araştırmaya etik kurulun olumlu görüşü alınmadan ve yetkili otoritenin izni olmadan başlanamayacağı ifade edilmiştir). Aynı anda başvuru yapılabilmesi durumunda Kurumun izin verdiği başvuruya etik kurul onay vermezse ne olacaktır? İlkesel olarak etik kurulun onay vermediği bir çalışmaya Kurum izin veremez. Başka bir ifadeyle Kurumun izin verebilmesinin ön koşulu başvurunun bilimsel ve etik yönden incelendiği bağımsız etik kurul onayıdır.

Çok merkezli klinik araştırmalarda tek etik kurul kararının bulunması yeterlidir. Söz konusu etik kurul kararının koordinatör merkezin bulunduğu yerdeki etik kuruldan alınması, burada etik kurul bulunmuyorsa çalışmaya dahil olan merkezlerden koordinatör merkeze en yakın yerdeki ilgili etik kuruldan karar alınması gerekmektedir. Tek merkezli klinik araştırmalarda ise araştırmanın yürütüldüğü merkezin bulunduğu yerdeki etik kuruldan karar alınması, etik kurul bulunmadığı takdirde araştırma merkezine en yakın yerdeki ilgili etik kuruldan karar alınması gerekmektedir.

Araştırma başvurusu, gerçek veya tüzel kişilerden oluşacak destekleyici tarafından ya da destekleyicinin görevlendireceği Türkiye'de ikamet eden sözleşmeli araştırma kuruluşu tarafından etik kurula ve Kuruma yapılır.

Yedinci fikrada geçen ve Kurum izni için belirlenen süreye (30 gün) ilâve olarak otuz günlük bir süre eklenebileceği söylenen genetik olarak modifiye edilmiş organizma taşıyan ürünler ile hücresel tedaviler veya gen tedavisi içeren ürünler kullanılarak yürütülecek araştırmalardan kapsam kısmında ve Yönetmeliğin başka bir yerinde bahsedilmemekte olup bunlar da Yönetmeliğin kapsamındaki araştırma tiplerine sokulmalıdır (Bakınız Tablo II). Bununla bağlantılı olarak 2001/20/EC say1l direktifte gen terapisi için tıbbi ürünler, ksenojenik hücre terapisi dahil somatik hücre terapisi ve genetik olarak modifiye edilmiş organizma taşıyan tüm tıbbi ürünlerden bahsedilmiştir (12).

\subsubsection{Klinik araştırmaların başlatılması ve yürütülmesi}

On üçüncü maddenin 2'inci fikrasına göre araştırmanın yürütülmesi sırasında meydana gelen değişikliklerden bildirim niteliğinde olanlar ile karar ve izin gerektirenler İKU K1lavuzu ile belirlenir. Karar ve izin gerektiren değişikliklerin etik kurul tarafından on beş gün içinde, Kurum tarafindan ise etik kurul kararının sunulmasından itibaren otuz gün içinde incelenerek sonuçlandırılması esastır.

Üçüncü fikrada ise araştırmalar yürütülme şeklinden bahsedilmektedir. Örneğin faz I klinik araştırmalarının ve biyoyararlanım-biyoeşdeğerlik çalışmalarının iyi klinik uygulamaları konusunda yeterli eğitim ve deneyime sahip uygun bir ekip ve uzmanlığını veya doktorasını yapmış tıp doktoru bir farmakolog tarafindan yürütüleceği hükme bağlanmıştır. Araştırma, Kurum tarafından izin verilmesine rağmen başvuru dosyasında belirtilen tarihte başlatılamamış ise başlatılamama sebepleri doksangüniçerisinde Kurumabildirilir. Destekleyici, yazılı sözleşme yapmak ve Kuruma bilgi vermek şartıyla, kendi görevlerinin bir kısmını bilimsel esaslara ve İKU'ya uygun şekilde çalışan sözleşmeli araştırma kuruluşuna devredebilir. Görevlerin sözleşmeli araştırma kuruluşuna devredilmesi, 
Tablo XI. Klinik Araştırmalar ile ilgili formlar.

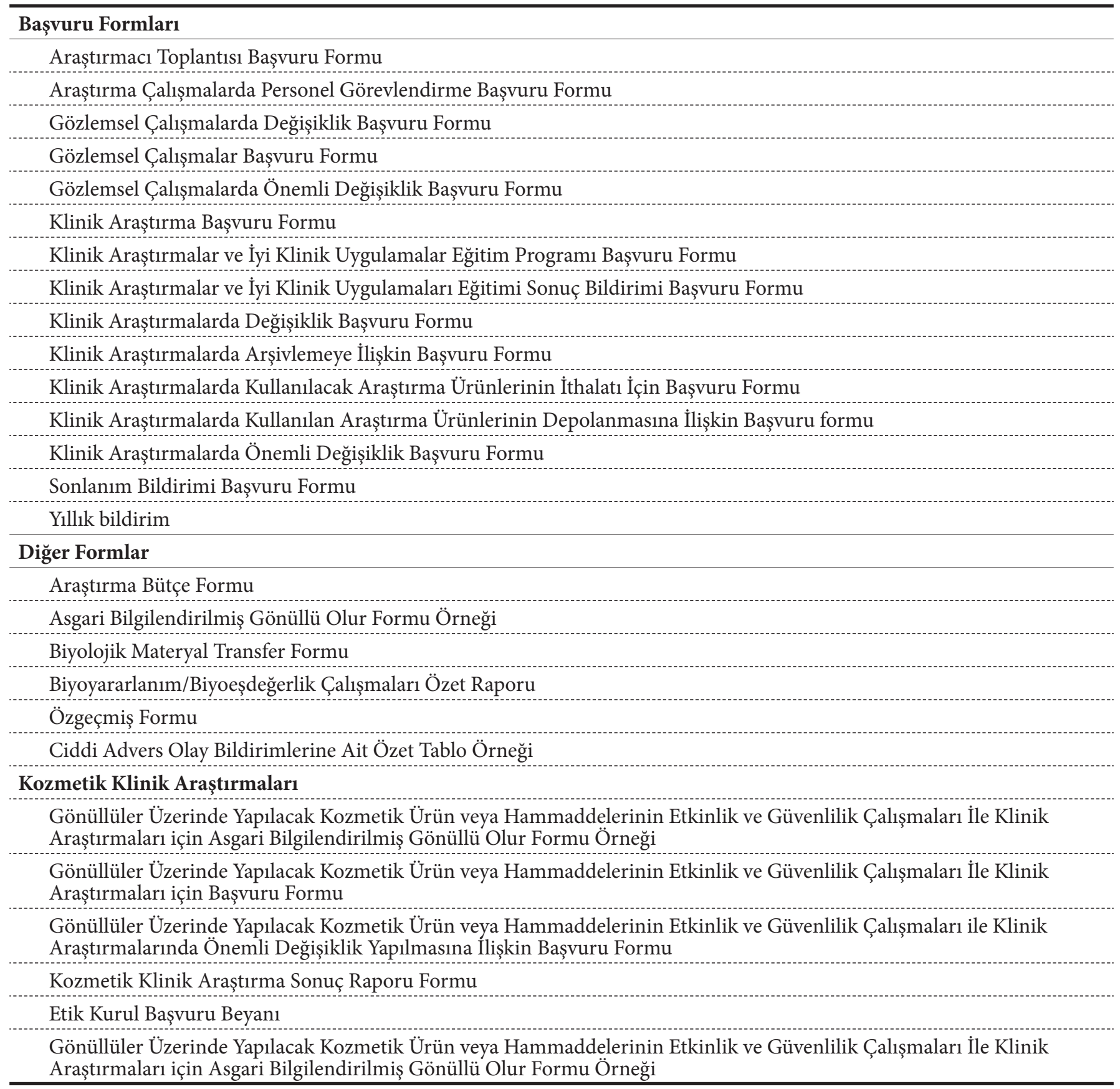

destekleyicinin devredilen hususlara dair muhtemel hukukî ve cezaî sorumluluğunu ortadan kaldırmaz. Destekleyici ve sözleşmeli araştırma kuruluşu, sözleşme konusu işlerin ve işlemlerin sonuçlarından birlikte sorumludurlar.

\subsubsection{Klinik araştırmaların durdurulması veya sonlandırılması}

Kurum, araştırmanın yürütülmesi sırasında araştırmaya izin verilirken mevcut şartlardan birinin ortadan kalktığını tespit ederse klinik araştırmayı derhal durdurur. Bu şartların belirlenen süre içerisinde yerine getirilmemesi veya yerine getirilmesinin mümkün olmadığının anlaşılması ya da bu süre zarfında gönüllü sağlığının tehlikeye girmesi hâllerinde araştırma doğrudan sonlandırılır. Araştırma başlatıldıktan sonra destekleyici tarafindan tamamlanmadan durdurulmuş ise, sebepleri ile birlikte durdurma kararı, çalışmaya alınmış olan gönüllülerin tedavisinin idamesine ilişkin tedbirleri içeren bilgi yazısı da eklenerek on beş gün içerisinde Kuruma ve etik kurula bildirilir. Destekleyici, araştırmanın bitmesinden itibaren doksan gün içerisinde araştırmanın sonlandığını Kuruma ve etik kurula bildirir.

\subsection{Dördüncü Bölüm}

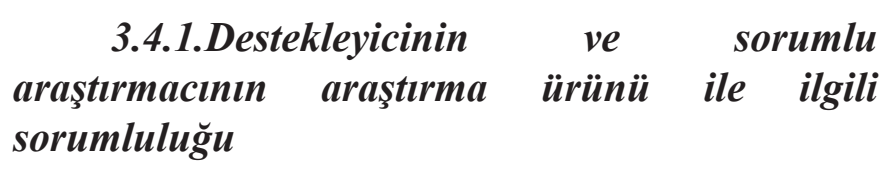


On beşinci maddenin ilk fikrasına göre araştırma ürününün uygun olarak depolanmas1, dağıtımı ve araştırma merkezine teslimi ile araştırma merkezinde bu koşulların devam ettirilmesi, kullanılmamış ürünlerin araştırma merkezinden toplanarak iadesinin sağlanması veya uygun şekilde imhası ve bütün bu sürece ait kayıtların tutulması destekleyicinin yükümlülüğü altındadır. İkinci fikrada ise araştırma ürünlerinin teslim alınması, muhafazası, yazılı istek veya araştırma protokolüne uygun dağıtımı, stok kontrolü, artan kısmına yapılacak işlemler ve kayıtlarının tutulması, araştırmanın yapıldığ 1 her bir merkezdeki sorumlu araştırmacının yükümlülüğü altında olduğu ifade edildikten sonra sorumlu araştırmacının bu işlemler için tercihen bir eczacıyı görevlendirebileceği ifade edilmiştir.

\subsubsection{Araștırma ürünlerinin imalatı, ithalatı ve etiketlenmesi}

Öncelikle araştırma ürünlerinin İyi İmalat Uygulamaları Kılavuzunda belirtilen kurallara uygun olarak imal edildiği garanti edilir. Daha sonra bunların imali veya ithali için Kurumdan izin alınır. Araştırma ürününün imalatını veya ithalatını yapacak olan destekleyici, şu hususları yerine getirir: i) Kuruma yapılacak başvuruda, imal veya ithal edilecek araştırma ürününe ait her bir serinin en azından iyi imalat uygulamaları standartlarına uygun koşullarda, dosyasında belirtilen ürün spesifikasyonlarına göre imalinin ve kontrolünün yapıldığının belgelemek, ii) araştırma yapmak amaciyla imal veya ithal edilen ürünlerin her serisine ait numuneler ile bunlara ait bilgi ve belgeler en az beş yıl süreyle saklamak, iii) araştırma ürününün dış ambalajında veya dış ambalajı yok ise en dışta bulunan hazır ambalajındaki etiketi İyi İmalat Uygulamaları Kılavuzuna uygun olarak ve Türkçe hazırlamak. Vurgulanması gereken önemli bir nokta "Beşerî Tıbbi Ürünlerin Tanıtım Faaliyetleri Hakkında Yönetmelik"in 9'uncu maddesinin 1'inci fikrasının $g$ bendine göre tanıtım numuneleri klinik araştırmalarda araştırma ürünü olarak kullanılamaz (20). Ayrıca klinik araştırmada araştırma ürünü olarak kullanılan ruhsatlı ürünlerin ülkemizdeki eczanelerden toptan alımı da kanunen yasaktır (14).

\subsubsection{Araştırma ürünlerinin geri çekilmesi}

Araştırmanın durdurulması hâlinde, sorumlu araştırmacı veya hekim ya da diş hekimi olan bir araştırmacının elinde kalan ürünlerin tamamı, destekleyici tarafından dağıtım yerlerinden derhal geri çekilir ve durum on beş gün içerisinde belgeleriyle birlikte ve bir rapor hâlinde Kuruma bildirilir ve bu ürünlerle ilgili yapılacak işlemler ve alınacak tedbirler Kuruma bildirilen raporda ayrıntılı olarak belirtilir.

\subsection{Beşinci Bölüm}

\subsubsection{Advers olayların bildirimi}

Sorumlu araştırmacı/araştırmacı ciddi advers olayların tamamını, protokolde veya araştırma broşüründehemenrapor edilmesigerekli görülmediği belirtilenler hariç, derhal destekleyiciye bildirmek zorundadır. Bu acil raporu, ayrıntılı yazılı bir rapor izler. Ayrıca araştırmaya iştirak eden gönüllülerden birinin ölümü durumunda destekleyiciye, etik kurula ve Kuruma istenilen her türlü ek bilgi sunulmalıdır. Destekleyici kendisine rapor edilen tüm advers olaylara ait kayıtları ayrıntılı olarak tutar. Bu kayıtlar talep edildiği takdirde Kuruma ve etik kurula sunulur.

\subsubsection{Ciddi advers reaksiyonların bildirimi}

Destekleyici, araştırma sırasında ortaya çıkan ölümle neticelenmiş veya hayatı tehdit edici şüpheli beklenmeyen ciddi advers reaksiyonlar hakkında, söz konusu bilgilerin kendisine ulaşmasından itibaren yedi günü geçmeyecek şekilde etik kurul ve Kurumu bilgilendirir. Bu vakalar hakkındaki ek bilgileri içeren izleme raporlarını, kendisine ulaşmasından itibaren sekiz gün içerisinde etik kurula ve Kuruma iletir. Diğer şüpheli beklenmeyen ciddi advers reaksiyonların tamamı (hastaneye yatmaya veya hastanede kalma süresinin uzamasına, kalıcı veya belirgin sakatlığa veya iş göremezliğe, doğumsal anomaliye veya doğumsal bir kusura neden olan advers reaksiyon), etik kurula ve Kuruma destekleyici tarafından, ilk bilginin edinilmesini takiben en geç on beş gün içerisinde bildirilir (21). Destekleyici, ayrıca tüm araştırmacıları ve sorumlu araştırmacıyı bilgilendirir. Destekleyici, araştırma süresince görülen şüpheli ciddi advers reaksiyonların tamamının listesini, gönüllü güvenliği ile ilgili bilgileri de içerecek biçimde, yılda bir kez, Kurumca yayımlanacak ilgili kılavuzlarda yer alan ara rapor formu ile birlikte etik kurula ve Kuruma bildirir.

\subsubsection{Diğer bildirimler}

Çok merkezli klinik araştırmalarda, ara rapor ve sonuç raporu, araştırmada yer alan merkezlerin 
tamamının araştırma ile ilgili sonuçlarını içerecek şekilde, ilgili kılavuzlar ve Kurumun internet sitesinde yayımlanan formlara göre hazırlanır. Araştırma ile ilgili görevlendirmelerden bildirim niteliğinde olanlar ile karar ve izin gerektirenleri İyi Klinik Uygulamaları Kılavuzu ile belirlenir. Bildirimlerin Kuruma düzenli olarak iletilmesinden destekleyici sorumludur.

\subsubsection{Araştırma kayıtları, gizlilik ve devri}

Araştırma ile ilgili kayıtların tamamı destekleyici ve sorumlu araştırmacı veya araştırmacı tarafından düzenli olarak tutulur ve araştırmanın bütün merkezlerde tamamlanmasından sonra en az beş yıl süre ile saklanır. Araştırma ile ilgili bilgi ve belgelerin arşivlenmesi ilgili kılavuz hükümleri gereğince yapılmalıdır. Araştırma ile ilgili belgelerin gizliliği esastır. Bu belgeler ancak hukuken yetkili kişilerin veya mercilerin talebi hâlinde yetkili kişilere verilir.

\subsubsection{Denetim}

Kurum, yurt içinde veya yurt dişında yürütülen araştırmaları, araştırmaların yapıldığı yerleri, destekleyiciyi ve sözleşmeli araştırma kuruluşunu, araştırılan ürünlerin imal edildiği yerleri, araştırma ile ilgili analizlerin yapıldığı laboratuvarları, etik kurulları, bu Yönetmelik ve ilgili diğer mevzuat hükümlerine uygunluğu yönünden, önceden haber vererek veya haber vermeden denetler. Denetçiler, lisans düzeyinde eğitim almış, iyi klinik uygulamaları konusunda yeterli eğitim ve deneyime sahip tercihen tıp ve eczacılık alanlarında eğitimli kişiler arasından seçilir.

\subsubsection{Sorumluluk}

Kurumca onaylanan araştırma protokolünde belirtilen ve araştırmada kullanılan her türlü araştırma ürününün, ürünlerin kullanılmasına mahsus cihaz ve malzemeler ile muayene, tetkik, tahlil ve tedavilerin bedeli destekleyici tarafından karşılanır. Bu bedel, gönüllüye veya Sosyal Güvenlik Kurumuna ödettirilmez. Ancak, kamu yararı bulunan ve Sosyal Güvenlik Kurumu tarafindan uygun görülen hâller saklıdır. Araştırmaya iştirak eden gönüllüden bilgilendirilmiş gönüllü olur formunun alınmış olması, gönüllünün araştırmadan dolayı uğradığı zararların tazminine ilişkin hakkını ortadan kaldırmaz.

\subsubsection{Yasaklar}

$\mathrm{Bu}$ Yönetmelik kapsamına giren araştırmaların bu Yönetmeliğe veya ilgili diğer mevzuatta belirlenen usûl ve esaslara aykırı olarak yapılması yasaktır. Önemli diğer bir nokta endikasyon dış1 kullanım izni alarak tedavide kullanılan ilaçlarla klinik araştırma veya gözlemsel çalışma yapılıp yapılamayacağı konusudur. Endikasyon Dışı İlaç Kullanımı Kılavuzu'nun yasaklar bölümünde "Sağlık Bakanlığı TİTCK tarafindan verilmiş izinler doğrultusunda yapılan tedaviler ve bunlardan elde edilecek sonuçlar, Sağlık Bakanlığı TITCK dışında bir kurum/kuruluş ve/veya kişi tarafından bilimsel yayın amaciyla (vaka takdimi hariç) ve ilaç ruhsatlandırma çalışmalarına esas veri olarak kullanılamayacağı" şeklinde düzenlendiğinden bu yönde bir çalışma veya yayın yapılamaz (22).

\subsection{8. İdarî yaptırımlar}

Klinik araştırmalara ilişkin hükümlerin ihlali hâlinde ilgili araştırma; uluslararası çok merkezli klinik araştırmalarda ise araştırmanın Türkiye'de yapılan kısmı Kurum tarafindan durdurulabilir veya sonlandırılabilir. Kurum, etik ilkelere uygun çalışmayan veya Kurumun yayınladığı Etik Kurul Standart Çalışma Yöntemi esaslarını yerine getirmeyen ya da yapılan denetim sonucunda etik kurul çalışmalarının yürütülebilmesi için zaruri olan mekân, sekretarya, arşiv ve sair ekipman yönünden eksiklik tespit edilen etik kurulu uyarır. Belirlenen süre içerisinde uyarı sebebinin giderilmemesi hâlinde, Kurum tarafindan verilen onay iptal edilir ve etik kurul başkanının üyeliği iki yıllık bir süre için düşürülür. Bu Yönetmelikte belirtilen hükümlere aykırı davranan ve faaliyette bulunanlar hakkında fiillerinin niteliğine göre 26/9/2004 tarihli ve 5237 sayılı Türk Ceza Kanunu (TCK) ve ilgili diğer mevzuat hükümleri uygulanır.

2004 yilında yenilenen TCK' de konu “İnsan Üzerinde Deney" başlığı altında düzenlenmiştir (23). Doksanıncı maddenin ilk fikrasında insan üzerinde bilimsel bir deney yapan kişinin bir yıldan üç yıla kadar hapis cezası ile cezalandırılacağ 1 belirtilmiştir (23). Aynı maddenin 2'inci fikrasında insan üzerinde yapılan bilimsel deneyin ceza sorumluluğu gerektirmemesi için gereken şartlar özetle şu şekilde ortaya konmuştur: i) Deneyle ilgili olarak yetkili kurul veya makamlardan gerekli iznin alınmış olması, ii) deneyin öncelikle insan dışı deney ortamında veya yeterli sayıda hayvan üzerinde yapılmış olması, iii) yapılan bu deneyler sonucunda ulaşılan bilimsel verilerin, varılmak istenen hedefe ulaşmak açısından bunların insan 
üzerinde de yapılmasını gerekli kılması, iv) deneyin, insan sağlığı üzerinde öngörülebilir zararlı ve kalıcı bir etki bırakmaması, v) deneyin mahiyet ve sonuçları hakkında yeterli bilgilendirmeye dayalı olarak açıklanan rızanın yazılı olması ve herhangi bir menfaat teminine bağlı bulunmaması (23). Üçüncü fikrada çocuklar üzerinde yapılan bilimsel deneyin ceza sorumluluğu gerektirmemesinin şartları şöyle tanımlanmıştır: i) Yapılan deneyler sonucunda ulaşılan bilimsel verilerin, varılmak istenen hedefe ulaşmak açısından bunların çocuklar üzerinde de yapılmasını gerekli kılması, ii) rıza açıklama yeteneğine sahip çocuğun kendi rızasının yanı sıra ana ve babasının veya vasisinin yazılı muvafakatinin de alınması, iii) deneyle ilgili izin verecek yetkili kurullarda çocuk sağlığı ve hastalıkları uzmanının bulunması (23). Dördüncü maddede ise "Hasta olan insan üzerinde rıza olmaksızın tedavi amaçlı denemede bulunan kişi, bir yıla kadar hapis cezası ile cezalandırılır" denilmiştir (23). Devamında ise "bilinen tıbbî müdahale yöntemlerinin uygulanmasının sonuç vermeyeceğinin anlaşılması üzerine, kişi üzerinde yapılan rızaya dayalı bilimsel yöntemlere uygun tedavi amaçlı deneme, ceza sorumluluğunu gerektirmez" ibaresi eklenmiştir (23). Açıklanan rızanın, denemenin mahiyet ve sonuçları hakkında yeterli bilgilendirmeye dayalı olarak yazılı olması ve tedavinin uzman hekim tarafından bir hastane ortamında yapılması diğer bir gereklilik olmuştur (23). Tedavi amaçlı deneme 2008 y1lında çıkarılan yönetmelikte "26/09/2004 tarihli ve 5237 sayıl1 TCK'nin 90'ınc1 maddesinin dördüncü fikrası kapsamında tanımlanmış "bilinen tıbbi müdahale yöntemleri ile tedavisi mümkün olmayan hastalarda veya bu tedavi yöntemlerinin yüksek riskli olduğu durumlarda; bilimsel araştırma sonuçlarının henüz kesin bir nitelik taşımadığ durumlarda dahi hastalığın tedavisi konusunda elde edilmiş somut bazı faydalarından yola çıkılarak, hastanın veya yasal temsilcisinin rizası alınmak suretiyle, uzman hekim tarafindan, hastanede yapılan ve bilimsel kurallara uygun olan tedavi" şeklinde tanımlanmıştır (2). TCK 90'ıncı maddenin 5 'inci fikrasında ise 1'inci fikrada tanımlanan suçun işlenmesi sonucunda mağdurun yaralanması veya ölmesi halinde, kasten yaralama veya kasten öldürme suçuna ilişkin hükümler uygulanacağı ifade edilmiştir (23). TCK'de geçen "bilimsel bir deney" kavramına klinik araştırmalardan hangilerinin dâhil edileceği, cezanın ağırlığı dikkate alındığında, önem arz etmektedir. Yeni araştırma ilaçlarının insanlarda ilk kez denendiği ve müdahaleli (girişimsel, deneysel) tasarımla yapılan faz I, II ve III çalışmaların bilimsel deney kapsamına gireceği çok aşikârdır. Aynı şekilde bakanlıkça ruhsatlandırılmış ve rutin tedavi hizmetlerinde kullanılmaya başlanan ilaçlarla yapılacak yeni endikasyon çalışmaları, daha önce çalışılmamış bir hasta grubu üzerinde yürütülecek uygulama çalışmaları ve öngörülen dozun üstünde, yüksek doz çalışmaları gibi tekrar faz III kapsamına alınarak müdahaleli tasarımla yapılacak çalışmalarda gönüllülere yapılan işlemin deney kapsamında düşünülmesi gerekebilir. Faz IV çalışmalara gelince, müdahaleli çalışma tasarımında da olsa gözlemsel olarak da yapılsa gönüllüye ruhsatlı bir ilaç ruhsatlı endikasyonunda verildiğinden yapılan işlemi deney olarak kabul etmek doğru olmaz.

\subsection{Altıncı Bölüm}

\subsubsection{Etik kurulların yapısı}

Etik kurullar gönüllülerin hakları, güvenliği ve esenliğinin korunması amaciyla araştırma ile ilgili diğer konuların yanı sıra gönüllülerin bilgilendirilmesinde kullanılacak yöntem ve belgeler ile bu kişilerden alınacak olurlar hakkında bilimsel ve etik yönden değerlendirme yapmak amaciyla, üyelerinin çoğunluğu doktora veya tıpta uzmanlık seviyesinde eğitimli sağlı meslek mensubu olan, iyi klinik uygulamaları ve klinik araştırmalar hakkında temel eğitim almış üyelerden oluşturulur. Aslında klinik araştırmaları bilimsel ve etik yönden değerlendirip onay verecek bir kuruldaki hukukçu ve sağlık meslek mensubu olmayan kişi dışında kalan üyelerin tamamının hekim olmasının zorunlu tutulması daha yerinde bir uygulama olurdu. Sorumlu araştırmacı bile olması öngörülmemiş olan eczacı, hemşire ve ebe gibi sağlı meslek mensupları ile biyolog, veteriner ve kimyacı gibi hastaya dokunması yetkisi dahi bulunmayan farklı mesleklerden gelen öğretim üyelerinin bir hekimin sunduğu dosya ve gönüllülerin güvenliği ve esenliği hakkında karar vermesi, açıkçası, pek de kabul edilebilecek bir durum değildir.

Etik kurullar üniversitelerde rektörün, Kamu Hastane Birliklerinde genel sekreterin, Gülhane Askeri Tıp Akademisinde dekanın teklifi ve Kurumun onayiyla kurulur ve bu onay tarihi itibariyle faaliyetlerine başlar. Bu düzenleme açık bir şekilde etik kurulların bağımsızlık ilkesi ile taban tabana zıtlık göstermektedir. Birincisi Yönetmeliğin tanımlar kısmında bile etik kurulların bağımsız kurullar olduğuna vurgu yapılmaktadır. İkincisi üyelerinin bizzat rektörün teklifi ve Kurumun 
onayı ile atandığı dolayısıyla bağımlı üyelerden oluşan böyle bir etik kurulun bağımsız olduğu iddia edilemez. Üyelerin bağımsız olabilmesi için adayların serbest seçimlerle belirlenmesi ve oluşan listenin rektörlük aracılığıyla Kuruma nitelik ve nicelik açısından teknik olarak incelemek üzere gönderilmesi daha uygun olur. Nitekim Helsinki Bildirgesi'nin 15'inci maddesi etik kurulların araştırmacı, destekleyici ve diğer unsurlardan bağımsız olması şartına atıfta bulunarak bağımsız kurulların oluşturulması gereğine işaret etmiştir (24). Buradaki diğer unsurlar açık bir şekilde düzenleme otoritesi olan Kurum ve araştırmanın yapılacağı yer ile ilgili (Rektör, Rektör Yardımcısı, Dekan, konu ile ilgili Enstitü Müdürü veya Merkez Müdürü, Kamu Hastaneleri Birliği Genel Sekreteri, Başhekim, Hastane Yöneticisi) tüzel ve özel kişilerdir. Bu bağlamda Yönetmelikteki "etik kurullarda klinik araştırma yapılan yerin üst yöneticileri görev alamaz" ibaresi bu ilkeyi desteklemektedir. Rektörün görev almasının yasaklandığı bir kurulun üyelerinin bizzat rektör tarafından teklif edilmesi kabul edilemez.

Yönetmeliğin bu son versiyonunda etik kurullar, Klinik Araştırmalar Etik Kurulu ve Biyoyararlanım-Biyoeşdeğerlik Çalışmaları Etik Kurulu şeklinde teşekkül ettirilmiştir (Tablo IV). Etik kurul üyelerinden en az üçü etik kurul sekretaryasının bulunduğu kurumun dişından belirlenir ve bir etik kurul üyesi birden fazla etik kurulda üye olamaz. Klinik farmakolojinin en önemli uygulama alanlarından biri olan klinik ilaç araştırmaları ile ilgili bir etik kurulun kadrosuna farmakolog olarak atanacak kişinin "farmakoloji alanında doktora yapmış veya bu alanda tıpta uzmanlık eğitimi almış kişi” olarak belirlenmesi ve tıp doktoru farmakolog olma zorunluluğunun kaldırılıp herhangi bir meslek grubuna ait birinin atanabilmesi rasyonel, bilimsel ve etik bir yaklaşım değildir. Klinik farmakoloji tıp fakültesi mezunu dolayısıyla hekim kökenli ve öncelikle de tıpta uzmanlık eğitimi almış farmakologların alanıdır; eczacı vb. kökenli farmakologların bu alanda yetkileri bulunmamaktadır. Sonuç olarak klinik ilaç araştırmalarında gerek etik kurula üye atanması gerekse sorumlu araştırmacı tayin edilmesi gerekiyorsa bunun şu şekilde düzenlenmesi gerekir: Klinik farmakoloji uzmanı tıp doktoru, yoksa tıbbi farmakoloji uzmanı tıp doktoru. Bilimsel gerçekler böyle iken ne yazık ki yıllar içerisinde sistematik olarak etik kurullardaki farmakolog üyenin niteliğinde, tıp doktorlarının aleyhine olacak şekilde, tahribat yapılmıştır (Tablo V). Batıda klinik farmakolog olabilmek için tıp fakültesi mezunu yani hekim olmak ön şarttır ve bu disiplin birçok yerde uzmanlık eğitimi olarak verilmektedir. Türkiye'de klinik farmakoloji uzmanlığ henüz bulunmamakla birlikte sadece hekimlerin alabileceği tıbbi farmakoloji uzmanlık eğitimi onun öncülü ve muadili olarak kabul edilmelidir. Farmakolojinin birçok alt dalı olmakla birlikte kabaca ilaçların insanlarda çalışılması anlamına gelen klinik farmakolojinin iki temel uğraşı alanı bulunur: i) Deney hayvanlarında etraflıca incelenmiş kimyasal maddelerin, sağlıklı ve hasta gönüllülerde belli kurallara göre denenmesi, değerlendirilmesi, uygun bulunanların ilaç olarak ruhsatlandırılması ve pazarlandıktan sonra takip edilmesi, ii) ilaçların tedavi prensiplerinin incelenmesi (25). Dolayısıyla merceğinde insanilaç ilişkisi olan klinik farmakoloji uzmanlı̆̆ının merkezinde de hekimlerin olması bir zorunluluktur. $\mathrm{Bu}$ nedenle klinik farmakolojinin uğraşı alanına giren ve merkezinde klinik farmakoloji uzmanlarının olduğu klinik araştırmalarda Türkiye koşullarında farmakolog olarak hekim olan tıbbi farmakoloji uzmanları öncelikli olarak müdahil olmalı ve sorumluluk almalidır.

\subsubsection{Etik kurulların çalışma usul ve esasları}

Etik kurulların çalışma usul ve esasları ana hatları ile şu şekilde tayin edilmiştir: i) Klinik araştırma başvurularını bilimsel ve etik yönden değerlendirme ve karar verme hususlarında bağımsız olmak, ii) etik kurul üyelerinin kendilerine ulaşan her türlü bilgi için gizlilik ilkesine uymak zorunda olmaları, iii) incelenen araştırmayla ilişkisi bulunan veya araştırmada görevi olan etik kurul üyesinin bu araştırmanın etik kuruldaki tartışmalarına ve oylamasına katılamaması ve etik kurul kararını imzalayamaması, iv) etik kurul üyelerinin üye tam sayısının üçte iki çoğunluğu ile toplanması ve üye tam sayısının salt çoğunluğu ile karar vermesi, v) etik kurulların çalışma yöntemlerinin Kurum tarafindan belirlenmesi.

\subsubsection{Etik kurulların görev ve yetkileri}

Etik kurullar, araştırma başvurusu hakkında görüş oluştururken asgari olarak şu noktalara dikkat ederler: i) Araştırmadan beklenen yarar, zarar ve risklerin analizini yapmak, ii) araştırmanın bilimsel verilere ve yeni bir hipoteze dayanıp dayanmadığını kontrol etmek, iii) insan üzerinde ilk defa yapılacak araştırmalarda, araştırmanın öncelikle insan dışı deney ortamında veya yeterli 
sayıda hayvan üzerinde yapılmış olması zaruretini gözetmek, iv) insan dışı deney ortamında veya hayvanlar üzerinde yapilan deneyler sonucunda ulaşılan bilimsel verilerin, varılmak istenen hedefe ulaşmak açısından araştırmanın insan üzerinde yapılabilecek olgunluğa erişip erişmediği ve bunun insan üzerinde de yapılmasını gerekli kılması hususunu değerlendirmek, v) araştırma protokolünü değerlendirmek, vi) araştırma broşürünün içeriğini değerlendirilmek ve usûlüne uygun düzenlenip düzenlenmediğini kontrol etmek, vii) araştırma ile ilgili olarak verilen yazılı bilgileri, gönüllü olurlarının alınması amaciyla izlenen yöntemi, kısitlılar, çocuklar, gebeler, lohusalar ve emziren kadınlar, yoğun bakımdaki ve bilinci kapalı kişiler üzerinde yapılacak araştırmalara ait gerekçenin yeterliliğini denetlemek, viii) araştırma sebebiyle ortaya çıkması muhtemel kalıcı sağlık problemleri de dâhil olmak üzere yaralanma veya ölüm hallerinde, sorumlu araştırmacı veya araştırmacı ya da destekleyicinin sorumluluğuna göz atmak, ix) araştırmaya bağlanabilecek bir yaralanma veya ölüm durumunda tazminat verilmesini sağlamak, x) gönüllülerin araştırmaya alınmasına ilişkin düzenlemeleri değerlendirmek ve xi) araştırmada görev alan araştırma ekibinin araştırmanın niteliğine göre uygunluğuna karar vermek.

Etik kurul kendisine yapılan başvurulardan onay alanları, gerektiğinde araştırma sırasında ve yerinde izleyebilir. Etik kurulun inceleme süreci içerisinde ek bilgi ve açıklamalara ihtiyaç duyulması hâlinde, gerekli olan tüm istekler tek bir seferde başvuru sahibine iletilir. İstenilen bilgi ve belgeler etik kurula sunuluncaya kadar inceleme süreci durdurulur.

Bu kısımda "e" bendinde bahsi geçen "genetik olarak modifiye edilmiş organizma taşıyan ürünler ile hücresel tedaviler veya gen tedavisi içeren ürünler kullanılarak yürütülecek araştırmalar" ve "ilaç dışı klinik araştırmalar" Yönetmeliğin kapsam kısmında ya da tanımlar bölümünde belirtilmemiştir. Geçmiş yönetmeliklere bakıldığında bu iki tip araştırma hakkında ipuçları bulunmaktadır. İlk olarak 2008 yılında çıkarılan Klinik Araştırmalar Hakkında Yönetmelik’te ilaç dışı klinik araştırmalardan bahsedilmiş ve endüstriyel olmayan ileri tıbbi ürün ile ileri tedavi edici tıbbi ürün bu bağlamda tarif edilmiştir (2). Daha sonra bu yönetmelikte 2010 yılında bir değişiklik yapılarak ilaç dışı klinik araştırmalar tanımlanmıştır (4). Ancak her iki yönetmelik mahkemece iptal edildiğinden yürürlükten kaldırılmıştır. Ancak daha sonra ne 2011 yılında ne de 2013 yılında çıkarılan yönetmeliklerde ilaç dışı klinik araştırmalar kavramı kullanılmamıştır $(8,9) .2014$ ve 2015 revizyonu da dahil olmak üzere en son çıkarılan 2013 yönetmeliğinde de, yukarıda işaret edildiği üzere, durum bu şekilde devam etmektedir. $\mathrm{Bu}$ nedenle geçmiş yönetmeliklerden hareketle dolaylı olarak ilaç dışı klinik araştırmaların, Yönetmelikte "e" bendinde ismi geçtiği için, bir sinıflamas1 yapılmas1 gerekmektedir (Bakınız Tablo VI). Yeni bir cerrahi metot araştırması ise hiçbir yönetmelikte ilaç dişı klinik araştırmalar içerisinde değerlendirilmemiş, 2008, 2010 ve 2011 yönetmeliklerinde ayrıca sınıflandırılarak etik kurul onay1 ve Kurum iznine tabi kılınmıştır $(2,4,8)$. Öte yandan güncel olan Yönetmelikte ise yeni bir cerrahi metot araştırması bahsi geçmemekle birlikte, Sağlık Hizmetleri Temel Kanunu'nun ek-10'uncu maddesindeki "herhangi bir tedavi yöntemi veya araçlarının veyahut ruhsat veya izin alınmış olsa dahi ilaç ve terkipleri, geleneksel bitkisel tıbbi ürünler ile tıbbi cihazların bilimsel araştırma amacıyla insanlar üzerinde kullanılabilmesi için, Sağlık Bakanlığından izin alınması gerekmektedir" ifadesi dikkate alındığında bu tip çalışmaların da etik kurul onayı ve Kurum izni gerektireceği anlaşılacaktır (6).

Yönetmelikte bahsi geçmeyen ancak Kurumun resmi internet sitesinde "sıkça sorulan sorular" başlı̆̆ 1 altında düzenlenen geleneksel ve tamamlayıcı tıp uygulamaları ile yapılan araştırmalarda etik kurul onayından sonra Sağlık Hizmetleri Genel Müdürlügü̈nden izin alınması gerekmektedir (26). Bu konuyla ilgili çıkarılan "Geleneksel ve Tamamlayıc1 Tip Uygulamaları Yönetmeliği”ne göre sertifikalı tabip/diş tabibi "geleneksel ve tamamlayıcı tıp uygulamaları ile ilgili olarak Bakanlıkça tescil edilmiş sertifikaya sahip tabip" tanımına karş1lık geldiğinden bu uygulamaları ancak bu kişiler yapabilir (26). Dolayısıyla da bu tip klinik araştırmalarda sorumlu araştırmacı sertifikalı tabip/diş tabibi olmak zorunda olup uygulama alanında temel eğitimi bulunan sağlık meslek mensupları merkez ve ünitelerde sertifikalı tabiplere uygulamada yardımcı olabildiklerinden araştırmacı olarak atanabilirler (26). Bu yönetmeliğin ekleri incelendiğinde bu kapsamdaki uygulamaların çeşitlerinin tanımlandığ 1 ve kimler tarafından yapılabileceklerinin aydınlatıldığı görülecektir (26). Benzer olarak insana doğrudan müdahale gerektirmeden yapılacak çalışmaların kapsamı ve bu çalışmaların yapılabilmesi için nereden onay alınması gerektiği de tanımlanmıştır. Buna göre Sağlık Bakanlığı ve bağlı kuruluşlarından 
izin alması zorunlu olan araştırmalar dışındaki, araştırmaya dâhil olan gönüllünün hastalığı için aldığı tedaviyi değiştirmemek veya etkilememek, araştırmaya dâhil olan gönüllüler sağlıklı bireyler ise yeni bir tedavi vermemek veya uygulama yapmamak kaydı ile tanımlamaya yönelik olarak yapılan Yönetmelik kapsamında olmayan ve Kurum denetiminde olmayan bağımsız etik kurulların denetleyeceği çalışma tipleri de mevcuttur (Tablo VII). Bu tip çalışmalar üniversitelerde senato kararı, kamu hastaneleri kurumlarında genel sekreterliğin onayı ile kurulan etik kurullarca veya Kurumca onaylı klinik araştırmalar etik kurulu ya da konusuna göre kozmetik klinik araştırmalar etik kurulunca değerlendirilir (14).

\subsection{Yedinci Bölüm}

\subsubsection{Klinik Araştırmalar Danışma Kurulunun yaptst}

Klinik Araştırmalar Danışma Kurulu, Sağlık Bakanlığı Müsteşarı veya uygun göreceği bir Müsteşar Yardımcısının başkanlığında tıbbın cerrahi, dâhili ve temel bilimlerinden Kurumca seçilen uzmanlığını almış veya doktorasını yapmış üçer kişi, birer klinik psikolog ve ilahiyatçı ile Kurum 1. Hukuk Müşaviri veya görevlendireceği bir hukuk müşavirinden oluşur.

\subsubsection{Klinik Araştırmalar Danışma} Kurulunun görevleri, çalışma usûl ve esasları

Klinik Araştırmalar Danışma Kurulu aşağıdaki görevleri yerine getirir: i) Klinik araştırmalarla ilgili olarak etik kurullarca tereddüt edilen ve sadece Kuruma yazılı olarak görüş almak üzere iletilen hususlarda bilimsel ve teknik yönden görüş bildirmek, ii) gönüllüler ve araştırmanın taraflarınca klinik araştırmalarla ilgili tereddüt edilen ve sadece Kuruma yazılı olarak görüş almak üzere iletilen hususlarda görüş bildirmek, iii) klinik araştırmalar politikalarına esas olmak üzere Bakanlığa görüş bildirmek.

\subsubsection{Gözlemsel ilaç çalışmaları}

Gözlemsel ilaç çalışmaları etik kurul onayı ve Kurumun izni olmadan yapılamaz. Bu tür çalışmalar ile ilgili esaslar Kurum tarafindan yayınlanacak k1lavuzla belirlenir. araştırmaları konularında eğitim almış nitelikli sorumlu araştırmacı veya araştırmacı, sağlık personeli ve bu alanda çalışan diğer kişilerin yetiştirilmesi amaciyla kurslar veya seminerler düzenleyebilir ya da Kurum tarafindan yayınlanacak kılavuz gereğince düzenlemek isteyen kurum ya da kuruluşlara düzenleme onayı verir.

\section{Tıbbi Cihaz Klinik Araştırmaları Yönetmeliği}

Genel olarak Yönetmeliğin tıbbi cihaza adapte edilmiş şekli olan ve 2014 yılında yayımlanan bu yönetmeliğin madde 2'deki kapsam kısm1 incelendiğinde gözlemsel tıbbi cihaz çalışmaları ile tüm tıbbi cihaz klinik araştırmalarının dâhil olduğu görülmektedir (Tablo II) (27). T1bbi cihazın ne olduğu hususu ile ilgili olarak 4'üncü maddenin z bendi diğer iki yönetmeliğe gönderme yapmaktadır (Aşağıya bakınız). Bunların yanında "vasıflı tıbbi uygulayıcı veya klinik araştırma yapmaya yetkili kişi tarafından yeterli klinik ortamda insan üzerinde; tıbbi cihazın normal kullanım koşullarındaki performansının veya normal kullanım koşullarındaki istenmeyen herhangi bir yan etkiyi ve bu etkinin tıbbi cihazın amaçlanan performansıyla kıyaslandığında kabul edilebilir bir risk oluşturup oluşturmadığının değerlendirilmesi amaciyla üretilen cihaz" olarak tanımlanan klinik araştırma amaçlı cihaz adı altında bir cihaz da tanımlanmıştır. Bununla ilgili olarak 17'inci maddenin 1'inci fikrasında "Üzerine "CE" işareti iliştirilmemiş cihazların klinik araştırma amaçlı kullanılabilmesi için imalatçısı ya da yetkili temsilcisi tarafından Tıbbi Cihaz Yönetmeliğinin ekinde yer alan Ek VIII'e uygun olarak hazırlanan beyanın Kuruma sunulmasının zorunlu olduğu" ifade edilmiştir. Madde 5/1/l'e göre "CE" işareti taşıyan ve tıbbi cihazın imalatçısı tarafından belirtilen kullanım amacı doğrultusunda yapılan tıbbi cihaz klinik araştırmalarında etik kurulun fayda-risk oranına göre uygun görmesi şartı ile sigorta aranmazken diğer tüm tıbbi cihaz klinik araştırmalarında gönüllülere sigorta yapılması şarttır. Madde $10^{\prime}$ da ise Klinik Araştırma Etik Kurullarının bu Yönetmelik hükümlerine tabi tüm tıbbi cihaz klinik araştırmalarını değerlendireceği hükme bağlanmıştır.

\section{Tıbbi Cihaz Yönetmeliği}

Tıbbi Cihaz Klinik Araştırmaları Yönetmeliği ile bağlantılı olan ve 2011 yılında çıkarılmış bulunan

\subsection{4. Ĕ̈itim}

Kurum, iyi klinik uygulamaları ve klinik 
"Tıbbi Cihaz Yönetmeliğì" dikkate alınması gereken bir başka belgedir (28). Bu yönetmeliğin amacı; tıbbi cihaz ve aksesuarlarının taşıması gereken temel gerekleri belirlemek ve bu cihazlar ile aksesuarlarının kullanımı sırasında hastaların, uygulayıcıların, kullanıcıların ve üçüncü şahısların sağlık ve güvenliği açısından ortaya çıkabilecek tehlikelere karşı korunmalarını sağlamak amacıyla tasarımına, sınıflandırılmasına, üretimine, piyasaya arzına, hizmete sunulmasina ve denetlenmesine ilişkin usul ve esasları düzenlemektir. Tıbbi cihaz bu yönetmelikte şu şekilde tanımlanmıştır: "İnsanda kullanıldıklarında aslî fonksiyonunu farmakolojik, immünolojik veya metabolik etkiler ile sağlamayan fakat fonksiyonunu yerine getirirken bu etkiler tarafindan desteklenebilen ve insan üzerinde hastalığın tanısı, önlenmesi, izlenmesi, tedavisi veya hafifletilmesi ya da yaralanma veya sakatlığın tanısı, izlenmesi, tedavisi, hafifletilmesi veya mağduriyetin giderilmesi ya da anatomik veya fizyolojik bir işlevin araştırılması, değiştirilmesi veya yerine başka bir şey konulması veyahut doğum kontrolü amaciyla kullanılmak üzere imal edilmiş, tek başına veya birlikte kullanılabilen, imalatçısı tarafından özellikle tanı ve/veya tedavi amaçlı kullanılmak üzere imal edilmiş ve tıbbi cihazın amaçlanan işlevini yerine getirebilmesi için gerekli olan yazılımlar da dâhil, her türlü araç, alet, teçhizat, yazılım, aksesuar veya diğer malzemeler". Aksesuar ise "kendi başına tıbbi cihaz sayılmayan ancak tıbbi cihazın amacına uygun bir şekilde kullanılmasını temin etmek için bu cihaz ile birlikte kullanılmak üzere imal edilen parça veya parçalar" şeklinde ifade edilmiştir. Konuyla ilgili diğer bir cihaz tipi omuz, diz ve kalça eklem değişimi cihazlarıdır ki bunlar "vida, çivi, plak gibi yardımcı bileșenler hariç olmak üzere; doğal bir omuz, diz veya kalça ekleminin işlevini yerine getirmek amacıyla vücuda yerleştirilebilir eklem değişim sisteminin bileşeni olan tıbbi cihazlar" olarak tanımlanmıştır.

Ayrıca bu yönetmeliğin kapsamında olan cihazlara şunlar da dâhil edilmiştir: i) Beşeri Tıbbi Ürünler Ruhsatlandırma Yönetmeliği kapsamına giren bir tıbbi ürünün uygulanması amacıyla üretilmiş cihazlar, ii) cihazdan bağımsız olarak kullanıldığında Beşeri Tıbbi Ürünler Ruhsatlandırma Yönetmeliği kapsamında tıbbi ürün olarak kabul edilen bir madde ile insan vücudu üzerindeki işlevine yardımcı olması amacıyla entegre edilerek kullanılan cihazlar, iii) cihazdan bağımsız olarak kullanıldığında Beşeri Tıbbi Ürünler Ruhsatlandırma Yönetmeliği kapsamında insan kanı veya plazmasından elde edilen bir tıbbi ürün (insan kanı türevi) olarak kabul edilen bir madde ile insan vücudu üzerindeki işlevine yardımcı olması amacıyla entegre edilerek kullanılan cihazlar. Diğer taraftan bu yönetmeliğin uygulanamayacağı durumlar da şöyle sıralanmıştır: i) İn vitro tıbbi tanı cihazları, ii) vücuda yerleştirilebilir aktif tıbbi cihazlar, iii) Beşeri Tibbi Ürünler Ruhsatlandırma Yönetmeliği kapsamına giren tıbbi ürünler, iv) Kozmetik Kanunu kapsamındaki kozmetik ürünler, v) insan kan1 türevleri hariç olmak üzere; insan kanı, kan ürünleri, insan kaynaklı plazma veya kan hücreleri ile insan hücresi, dokusu, nakil organları veya bunlardan imal edilen ürünler, vi) cansız hayvan dokuları ve cansız hayvan dokularından imal edilen ürünleri içeren tıbbi cihazlar hariç olmak üzere, hayvan kökenli doku ve hücreler. İn vitro tıbbi tanı cihazı tanımı ise " $\mathrm{g}$ " bendinde şöyle tanımlanmıştır: İmalatçı tarafından esas olarak; fizyolojik veya patolojik durum ile ilgili bilgi edinmek veya konjenital anomalilerle ilgili bilgi edinmek ya da muhtemel alıcılar için uygunluk ve güvenliği belirlemek veyahut tedaviyi izlemek amacıyla tek başına veya birlikte kullanılmasına bakılmaksızın, kan ve doku bağışları da dahil olmak üzere insan vücudundan alınan numunelerin in vitro incelenmesi için tasarlanan reaktif, reaktif ürünü, kalibratör, kontrol materyali, kit, araç, gereç, ekipman veya sistem olan bütün tıbbi cihazları ve bu numunelerin muhafaza edilmesi amaciyla kullanılan vakumlu veya vakumsuz numune kapları.

Klinik araştırmalar, yönetmeliğin 15 'inci maddesinde düzenlenmiştir. Buna göre klinik araştırma amaçlı cihazlar (CE (Conformité Européenne) işareti olmayan) ve CE işareti taşıyan tıbbi cihazlar açısından iki ayrı yaklaşım söz konusudur. Birinci durumda imalatçı veya yetkili temsilci, sinif III tıbbi cihazlar ile Sinıf IIa veya IIb'ye dâhil olan implant ve uzun süreli invaziv cihazlar hakkında, ilgili Etik Kurulun onayı ile birlikte klinik araştırma talebini Bakanlığa bildirir (Ek IX'da sınıflandırılma kuralları anlatılmıştır). Bakanlık bildirim tarihinden 60 (altmış) gün sonra klinik araştırma talebini sonuçlandırır. Yukarıda belirtilen cihazlar dışındaki tıbbi cihazlar söz konusu olduğunda, ilgili Etik Kurulun araştırma planına kendi gerekçesini eklemek suretiyle olumlu görüş vermesi halinde, Bakanlık imalatçılara hemen klinik araştırma başlatmaları için izin verebilir. Klinik araştırma, CE işareti taşıyan tıbbi cihazlar kullanılarak tıbbi cihazın uygunluk değerlendirme işlemlerinde belirtilen amaç için yapılıyorsa, bunun için sadece bu yönetmelikteki Ek X'un 
ilgili hükümleri uygulanır. Klinik araştırmaların amaçları iki başlık halinde ek X'da vurgulanmıştır: i) Tıbbi cihazın normal kullanım koşullarındaki performansının değerlendirilmesi, ii) normal kullanım koşullarındaki istenmeyen herhangi bir yan etkiyi ve bu etkinin tıbbi cihazın amaçlanan performansıyla kıyaslandığında kabul edilebilir bir risk oluşturup oluşturmadığının değerlendirilmesi. Ayrıca klinik araştırmanın Helsinki Bildirgesi çerçevesinde uygulanması zorunlu olduğu da hatırlatılmıştır.

\section{Vücuda Yerleştirilebilir Aktif Tıbbi Cihazlar Yönetmeliği}

Yukarıda bahsi geçen Tibbi Cihaz Yönetmeliğinin aktif tıbbi cihazlara uyarlanmış şekli olan bu yönetmelikte geçen aktif tıbbi cihaz "yer çekiminin ya da insan vücudunun doğal olarak oluşturduğu enerji haricinde herhangi bir elektrik enerjisi veya güç kaynağıyla çalışan tıbbi cihazlar" olarak tanımlanmıştır. Benzer olarak vücuda yerleştirilebilir aktif tıbbi cihaz ise "tamamı veya bir k1smı, tıbbi veya cerrahi bir müdahale ile insan vücuduna ya da doğal bir vücut girişine veya boşluğuna yerleştirilen ve yerleştirildiği yerde kalması gereken aktif tıbbi cihazlar" şeklinde tanımlanmıştır (29). Klinik araştırmalarla ilgili hükümler de Tibbi Cihaz Yönetmeliği ile büyük oranda benzerlikler göstermektedir.

\section{Kozmetik Ürün veya Hammaddelerinin Etkinlik ve Güvenlilik Çalışmaları ile Klinik Araştırmaları Hakkında Yönetmelik}

Gönüllüler üzerinde yapılacak olan kozmetik ürün veya hammaddelerinin etkinlik çalışmaları, güvenlilik çalışmaları veya klinik araştırmalarının yürütülmesi, kayıtlarının tutulması, rapor edilmesi, geçerliliği ve diğer hususlarda bilimsel ve etik standartların sağlanması ve gönüllülerin haklarının korunmasına dair usûl ve esaslar ile Kozmetik Klinik Araştırmalar Etik Kurullarının teşkili, görevleri, çalışma usûl ve esaslarını düzenlemek amacıyla 2015 yılında TİTCK tarafindan bu yönetmelik çıkarılmıştır (30). Tanımlar kısmında kozmetik hammadde ve kozmetik ürün sırasıyla şu şekilde tanımlanmıştır: i) Tek başına veya karışım hâlinde kozmetik ürün içinde kozmetik etki sağlamak amacıyla veya yardımcı bileşen olarak kullanılan madde, ii) insan vücudunun dış kısımlarına; epiderma, tırnaklar, kıllar, saçlar, dudaklar ve dış genital organlarına veya dişler ile ağız mukozasına uygulanmak üzere hazırlanmış, tek veya temel amac1 bu kısımları temizlemek, koku vermek, görünümünü değiştirmek, bunları korumak, iyi bir durumda tutmak veya vücut kokularını düzeltmek olan bütün madde veya karıșımlar. Bu maddelerle yapılacak araştırmalardan biri kozmetik ürün veya hammaddelerinin etkinlik veya güvenlilik çalışmaları olup "kozmetik ürün veya hammaddelerinin etkinlik veya güvenlilik iddialarını araştırmak amacıyla gönüllüler üzerinde yürütülen çalışmalar" olarak tanımlanmıştır. Bir diğeri ise "bir veya birden fazla kozmetik ürünün klinik etkilerini ortaya çıkarmak ya da doğrulamak, istenmeyen etkilerini tanımlamak, emilim, dağılım, metabolizma ve atılımlarını tespit etmek amaciyla insanlar üzerinde yapılan çalışma veya araştırmalar" olarak açıklanan kozmetik ürün veya hammaddelerinin klinik araştırmalarıdır. Klinik ilaç araştırmalarından farklı olarak buradaki sorumlu araştırmacının hekim olmasına gerek duyulmamış olup çalışma veya araştırma konusu ile ilgili dalda, çalışma veya araştırmanın gerektirdiği seviyede eğitimini tamamlamış, çalışma veya araştırmanın yürütülmesinden sorumlu olan herhangi bir kişi bu araştırmaları yürütebilir. Burada bahsi geçen araştırmalar hakkından bilimsel ve etik yönden görüş vermek üzere TİTCK tarafindan Kozmetik Klinik Araştırmalar Etik Kurulu teşkil edilir (Tablo VIII). $\mathrm{Bu}$ araştırmaların başvuruları, gerçek veya tüzel kişilerden oluşacak destekleyici, destekleyicinin görevlendireceği sözleşmeli araştırma kuruluşu veya sorumlu araştırmacı tarafindan Kuruma, yani TİTCK'e, yapılır. Kurumca değerlendirilen başvurulardan etik kurul izni alınması gerekenler etik kurula yönlendirilir. Klinik Araştırmalar Danışma Kurulu ise tüm kozmetik klinik araştırmalarında etik kurul kararlarına yapılacak itirazları, etik kurullarla ilgili şikâyetleri ve klinik araştırmalarla ilgili olarak etik kurullarca veya klinik araştırmanın taraflarınca Kuruma iletilen ve uzmanlık görüşü gerektiren hususlarda görüş bildirmek üzere kurulmuştur.

\section{Sonuçlar}

1993 yılında yayımlanan ilk yönetmelikten günümüzde yürürlükte olan son yönetmeliğe kadar konuyla ilgili birçok kanun, yönetmelik ve yardımc1 belge niteliğinde kılavuz yayımlanmıştır. Tüm bu süreç mercek altına alındığında özellikle Avrupa Birliği direktiflerinin stimüle etmesiyle inişleri ve çıkışları olsa da pozitif bir evrim yaşandığ 1 söylenebilir. Günümüz koşullarında TITCK'in internet sitesinde birçok yardımcı kılavuzun olduğu görülmektedir. Bu kılavuzlar da dikkate alındığında 
klinik araştırmalar mevzuatının ciddi bir hacme ulaştığı ve konuyla ilgilenen tarafların okuma yükünün her geçen gün arttığı tespiti yapılabilir. Başta İyi Kinik Uygulamaları kılavuzu olmak üzere konuyla yakından ilişkili kılavuzlar başlık halinde Tablo IX' da özetlenmiştir. Bunların yanında TITCK internet sitesinde onlarca başvuru formu da bulunmaktadır ki etik kurul üyeleri, destekleyici ve araştırmacıların bunlara hakim olması da önem arz etmektedir(TabloX). Son olarak klinik araştırmaların merkezinde bulunan klinik ilaç araştırmaları klinik farmakoloji disiplinin merceği altında olan en önemli konulardan biridir. Klinik farmakoloji uzmanlığ sadece tıp doktorlarının elde edebileceği bir unvandır ve bunun Türkiye'deki öncülü ve muadili tıbbi farmakoloji uzmanlığıdır. Bu nedenle tıbbi farmakoloji uzmanlığ uzmanlığına evrilmesi amaciyla desteklemelidir. Elbette klinik ilaç araştırmaları multidisipliner bir süreçtir; bunun içinde başta klinisyen tıp doktorları olmak üzere değişik meslek grupları bulunacaktır. Ancak klinik araştırmalarda eğer bir farmakolog gerekirse bu durumda öncelik klinik farmakoloji uzmanlarının Türkiye'deki karşılığı olan tıbbi farmakoloji uzmanlarına verilmek zorundadır.

\section{KAYNAKLAR}

1. İlaç Araştırmaları Hakkında Yönetmelik. Resmi Gazete yayım tarihi: 29/01/1993; Sayı: 21480.

2. Klinik Araştırmalar Hakkında Yönetmelik. Resmi Gazete yayım tarihi: 23/12/2008; Sayı: 27089.

3. T.C. Danıştay Onuncu Daire. Esas No: 2009/3991; Tarih: 13/11/2009.

4. Klinik Araştırmalar Hakkında Yönetmelikte Değişiklik Yapılmasına Dair Yönetmelik. Resmi Gazete yayım tarihi: 11/03/2010; Sayı: 27518.

5. T.C. Danıştay İdari Dava Daireleri Kurulu. Karar: YD itiraz no: 2010/164; Karar tarihi: 15/07/2010.

6. 3359 sayılı Sağlık Hizmetleri Temel Kanunu kanuna eklenen ek madde 10. Kabul tarihi: 06/04/2011; Kanun no: 6225.

7. Sağlık Bakanlı̆̆ ve Bağlı Kuruluşlarının Teşkilat ve Görevleri Hakkında Kanun Hükmünde Kararname. Resmi Gazete yayım tarihi: 02/11/2011; Say1: 28103.

8. Klinik Araştırmalar Hakkında Yönetmelik. Resmi Gazete yayım tarihi: 19/09/2011; Say1:
28030.

9. Klinik Araştırmalar Hakkında Yönetmelik. Resmi Gazete yayım tarihi: 13/04/2013; Sayı: 28617.

10. Klinik Araştırmalar Hakkında Yönetmelikte Değişiklik Yapılmasına Dair Yönetmelik. Resmi Gazete yayım tarihi: 25/06/2014; Sayı: 29041.

11. İlaç Ve Biyolojik Ürünlerin Klinik Araştırmaları Hakkında Yönetmelikte Değişiklik Yapılmasına Dair Yönetmelik. Resmi Gazete yayım tarihi: 13/09/2015; Say1: 29474.

12. Avrupa Birliği’nin İyi Klinik Uygulamaları hakkındaki 2001/20/EC sayılı direktifi

13. Avrupa Birliği'nin İyi Klinik Uygulamaları hakkındaki 2005/28/EC say1lı direktifi

14. http://www.titck.gov.tr/Dosyalar/Ilac/ KlinikArastirmalar/KlinikArastirmalarSSS.pdf

15. Tıbbi Cihaz Klinik Araştırmaları Yönetmeliği. Resmi Gazete yayım tarihi: 06/09/2014; Say1: 29111.

16. Kozmetik Ürün veya Hammaddelerinin Etkinlik ve Güvenlilik Çalışmaları ile Klinik Araştırmaları Hakkında Yönetmelik. Resmi Gazete yayım tarihi: 20/09/2015; Sayı: 29481.

17. Avrupa Birliği'nin Sahipli T1bbi Ürünler hakkındaki 65/65/EEC sayılı direktifi.

18. Beşeri Tıbbi Ürünlerin Ruhsatlandırma Yönetmeliği. Resmi Gazete yayım tarihi: 19.01.2005; Sayı: 25705.

19. Türk Medeni Kanunu. Kabul Tarihi: 22.11.2001; Kanun No: 4721.

20. Beşerî Tıbbi Ürünlerin Tanıtım Faaliyetleri Hakkında Yönetmelik. Resmi Gazete yayım tarihi: 03.07.2015; Sayı: 29405.

21. İlaçların Güvenliliği Hakkında Yönetmelik. Resmi Gazete yayım tarihi: 15.04.2014; Say1: 28973.

22.http://www.titck.gov.tr/Mevzuat/ MevzuatGetir?id=2637

23. Türk Ceza Kanunu. Resmi Gazete yayım tarihi: 12/10/2004; Say1: 25611.

24. Helsinki Deklarasyonu. 2013: Yedinci revizyon; 64. Toplant1, Fortaleza.

25. Principles of Clinical Pharmacology. Atkinson AJ, Huang S-M, Lertora JJL, Markey SP. Third edition, 2012. Academic Press, Elsevier, UK. 
26. Geleneksel ve Tamamlayıcı Tıp Uygulamaları 29. Vücuda Yerleştirilebilir Aktif Tibbi Cihazlar Yönetmeliği. Resmi Gazete yayım tarihi: Yönetmeliği. Resmi Gazete yayım tarihi: 27/10/2014; Say1: 29158. 07/06/2011; Say1: 27957.

27. Tıbbi Cihaz Klinik Araştırmaları Yönetmeliği. 30. Kozmetik Ürün veya Hammaddelerinin Resmi Gazete yayım tarihi: 06/09/2014; Say1: 29111.

28. Tıbbi Cihaz Yönetmeliği. Resmi Gazete yayım Etkinlik ve Güvenlilik Çalışmaları ile Klinik Araştırmaları Hakkında Yönetmelik. Resmi Gazete yayım tarihi: 20/09/2015; Say1: 29481. tarihi: 07/07/2011; Sayı: 27957. 